\title{
Flow cytometry as a tool for the study of phytoplankton*
}

\author{
G.B.J. DUBELAAR ${ }^{1}$ and R.R. JONKER ${ }^{2}$ \\ 'Dubelaar Research Instruments Engineering, Zeelt 2, 2411 DE, Bodegraven, The Netherlands. \\ Fax + 31(0)172615 219. email: george@dubelaar.net \\ ${ }^{2}$ AquaSense B.V., Kruislaan 411A, P.O.box 95125, 1090 HC Amsterdam, The Netherlands
}

\begin{abstract}
SUMMARY: An overview is presented on flow cytometry as a tool for counting, analysis and identification of phytoplankton species and groups. The paper covers basics on the analysis technique and instrumentation such as the measuring principle, the type of instrument, limitations and pitfalls with phytoplankton samples and sample handling and preprocessing. Possibilities of the measured entities are discussed, roughly divided in light scatter and related parameters, the endogenous fluorescence and exogenous fluorescence, followed by a discussion on the actual applications such as phytoplankton abundance analysis, ecology and physiology research and monitoring of particle size and biomass. In addition to a limited literature review, we tried to assess how flow cytometry is used in routine laboratory practice and monitoring operations. Therefore, a questionnaire was sent out via email to 47 scientists at 43 institutes known to us as involved in flow cytometric analysis of phytoplankton. In total, 19 scientists responded. Specific survey results are included in italic print whereas some more general answers were integrated in the overview.
\end{abstract}

Key words: flow cytometry, phytoplankton, marine, fresh water, monitoring, counting, identification, fluorescence, particle analysis.

\section{INTRODUCTION}

The aquatic environment is subject to dynamic processes on widely varying time and space scales. The scale of the smallest independent biological unit, the cell, remains a key scale for interpretation and calibration of data. Although traditional microscopical analysis is unsurpassed regarding species identification power, there are drawbacks in terms of enumeration, quantitative character and speed. Flow cytometry allows fast counting and optical analysis of individual particles, although with less detailed species discrimination. Li (1995) for instance

\footnotetext{
*Received June 14, 1999. Accepted March 24, 2000.
}

showed with flow cytometry that Prochlorococcus spp. comprised $78 \%$ of the cells of central North Atlantic Ocean ultraphytoplankton, representing $28 \%$ of total fluorescence, a measure of chlorophyll biomass, and about $11 \%$ of total light scattering, being a measure of carbon biomass. In addition, the high number of cells analysed by flow cytometry permits more statistically significant results, important for instance to study population and community structures, as shown also by Gisselson et al. (1999) who used cell cycle analysis to estimate in situ gross growth rates. The first flow cytometric studies in aquatic sciences were published over a decade ago (Paau et al., 1978, 1979; Trask et al., 1982; Yentsch et al., 1983a). Milestones were the special issue of 
Cytometry (Yentsch and Horan, 1989) and the NATO Advanced Study Institute on Individual Cell and Particle Analysis in Oceanography (Demers, 1991). Overviews were presented by Yentsch (1990) and Olson et al. (1991). Samples containing fresh water or coastal water phytoplankton populations are much more heterogeneous in terms of size, morphology and concentration as compared to the blood cell samples for which flow cytometers were originally developed. Aquatic field samples are analysed quite regularly though in the practice of aquatic science, mainly using commercially available standard equipment, and occasionally using experimental instrumentation. Particles in the open oceans are usually small, allowing oceanographers to use flow cytometers without many problems, which led to the discovery of Prochlorococcus (Chisholm et al., 1988), and the determination of the "smallest eukaryotic organism" (Courties et al., 1994). Detection of 'new' species or groups using flow cytometry still occurs (Corzo et al., 1999). Parallel to the increasing application to algae, and with the advent of more sensitive optics, flow cytometers were also used to measure aquatic bacteria (Button and Robertson, 1990), contributing to the awareness of the importance of aquatic bacteria over the past years (Azam and Smith, 1991). Robertson and Button (1989) developed procedures for characterizing aquatic bacteria according to population, cell size, and apparent DNA content. Endo et al. (1997) described a rapid flow cytometry technique based on fluorescein diacetate to distinguish between viable cells and dead cells for various sea water bacteria. Flow and image cytometry were used by Sieracki $e t$ al. (1995) to demonstrate overestimation of heterotrophic bacteria in the Sargasso Sea by standard microscopical technique. The most recent achievements in terms of detection of small particles are the enumeration of aquatic viruses (Marie et al. 1999), making FCM a potentially useful tool for studies of the structure and dynamics of virus populations in natural waters and basic virus-host cell interactions (Brussaard et al. 1999).

All institutes of the survey are or were using flow cytometry for the analysis of field samples. Twelve institutes say they use, used or will use flow cytometry on a routine basis. The 9 institutes who are currently doing regular analysis of field stations have sampling strategies varying from weekly to yearly analysis, depending on water type (estuarine $>$ shelf $>$ oceanic), logistics (close to the lab $>$ far away) or otherwise. The combined numbers of stations cov- ered are: 17 stations at a weekly or biweekly basis, 13 stations at a monthly or bimonthly interval and more than 20 stations once per season or year. Sample collection varies between 1 and 10 depths sampled per station. The total number of field samples processed annually varies from about 50 to about 1000 per laboratory. Besides daily laboratory operation, 7 institutes employ the flow cytometers on research cruises on a more or less regular basis. During the cruises, typical strategies are daily analysis of depth profiles, up to sampling every few hours.

\section{TECHNOLOGY}

\section{Measuring principle}

Figure 1 is a schematic presentation of the measuring principle and data processing of a flow cytometer. Flow cytometers measure light scatter and fluorescence of particles passing a zone of intense illumination, carried and centred inside a high speed water jet, free flowing in air or in a quartz flow cuvette. Most cytometers use a laser for illumination. Laser light is monochromatic, with ultraviolet, visible or near infrared lines. Small air cooled argon lasers delivering 488 and $515 \mathrm{~nm}$ beams of up to about $100 \mathrm{~mW}$ are most commonly used. The cells are pumped in a single file through the analysis point at typically 1,000 cells or more per second, with a practical analysis speed of 1-5 minutes per sample. The successive scattering and fluorescence signals generated by each passing particle are detected by photomultiplier tubes or photodiodes. The detection sensitivity is sufficient to analyse submicron particles. The electronics interface converts these raw signals into correlated digital data, stored on disc for data analysis and presentation as distributions (univariate) or multivariate scatterplots or grey/colour maps. Instruments may have a sorting device, allowing the physical separation of selected cells from the main stream during analysis (Reckermann, 2000). Wallner et al. (1997) sorted bacteria from lake water and sediment based on differences in light scattering, DNA content, and/or using rRNA-targeted oligonucleotide probes. The cells of a single population give similar results, showing as a single peak in a univariate distribution, or a close group of data points in a multidimensional scatter plot. In addition to the instrumental properties, it is the biological variance, such as differences in cell size, life cycle, pigment content etc., 


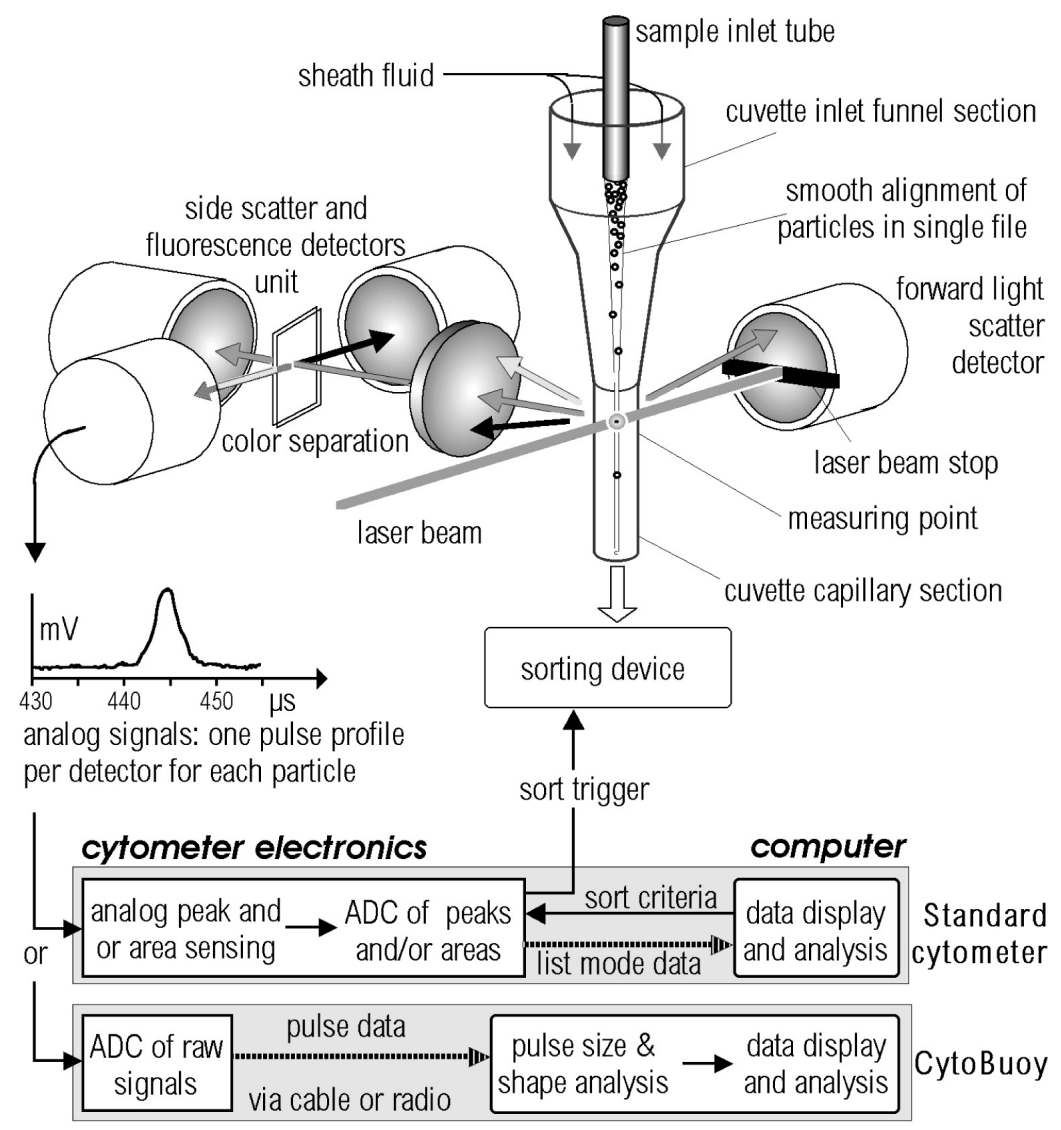

FIG. 1. - Schematic drawing of the flow cytometer operating principle and signal processing. The sample is injected in a sheath fluid that funnels it into a thread, so thin that the particles are well separated, intersecting a focussed laser beam one by one at high flow speed. Here, each particle emits a short (typically a few microseconds) flux of photons by scattering or fluorescing. Photodetectors convert those into electrical pulses. Small particles give similar, gaussian shaped pulses, following the distribution of light in the laser focus. From these signals (top electronics panel), either the pulse maximum or the pulse area is sensed with analog electronics, subsequently digitized and stored on computer disc in so-called list mode data files. In these files each detected particle is listed with its indiviual pulse values, one for each detector. The directly available listmode data per cell may also be used to control a sorting module for the real-time physical selection (flow sorting) of particles downstream of the laser focus. The shape and length of big diatoms and filaments dominate their detector pulses, impairing analog electronic processing. This requires direct digitization of the detector output (lower panel) to obtain correct pulse area (integral) values and to allow any other type of pulse analysis in principle, as applied in the CytoBuoy instrument (Dubelaar et al., 1999, Dubelaar and Gerritzen, this volume).

that causes the variance seen as the width of the peaks or clusters (Campbell et al., 1989a, b, c). With mixed cultures or field samples, more clusters appear, more or less separated, representing groups with different optical properties. Figure 2 shows a typical bivariate plot of a sample containing several species. The data points from a cluster can be selected to yield distributions of physiological properties of the cells belonging to this group (Li, 1990; Demers et al., 1992). Exploration of data analysis tools such as multivariate curve-fitting and diversity indices is important in this respect. The discriminating power of the analysis increases if more independent optical properties of the particles are measured, or if specifically binding fluorescent probes are used. This is important to allow classification of the
particles.Whereas in the biomedical field, the cytometrist is faced with perhaps four to six or so cell types to differentiate, in marine waters the numbers of cell types are typically up to an order of magnitude greater. The development of procedures for automated data analysis is crucial. Recent advances achieved in neural network computing are promising (Smits et al., 1992; Balfoort et al., 1992b; Frankel et al., 1989, 1996; Wilkins et al., 1996; Jonker et al., 2000).

\section{Commercial instruments}

The number of flow cytometers world wide is probably around the 10.000 figure. Designed for analysis and sorting of mammalian cells, by far the 


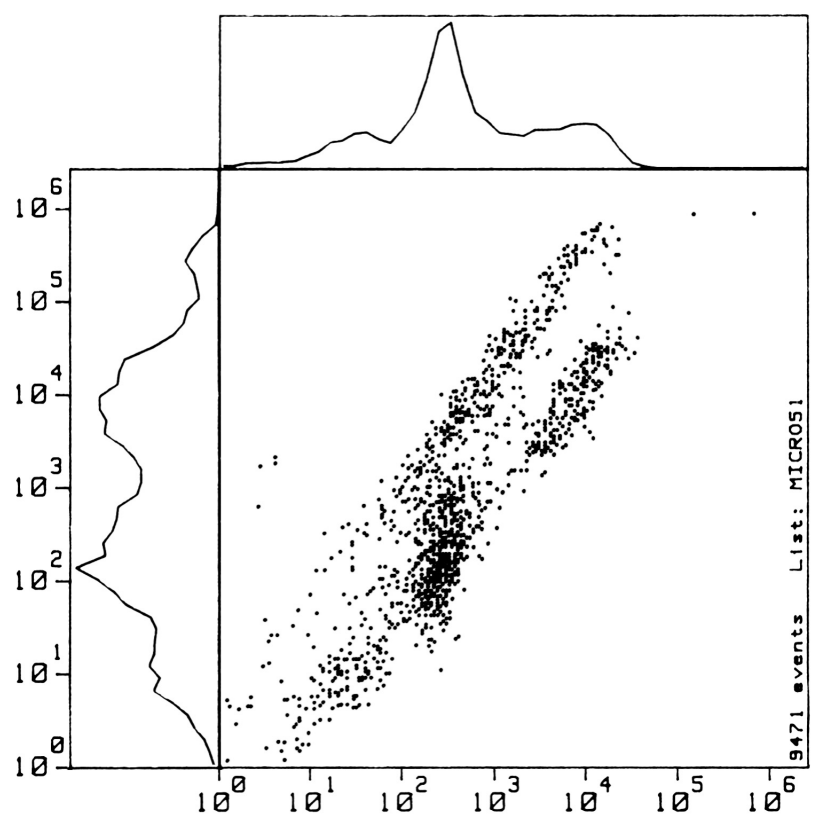

FIG. 2. - An example of a bivariate scatter plot, with corresponding univariate frequency distributions, of a fresh water field sample containing single cells and some colony forming cyanobacterial species, measured with an OPA flow cytometer. Vertical axis $=$ side scatter; horizontal axis = forward scatter. Each dot in the scatter plot represents an individual particle. The frequency distributions show the number of particles versus their measured forward or side scatter value (horizontal and vertical distribution respectively, numbers normalized to fit the frame).

largest part, say about $95 \%$ of the instruments are used in biomedical applications. The rest are employed in a variety of fields such as pharmaceutical industry, food and beverages industry, diary industry, botany, marine science, limnology and drinking water industry. Becton Dickinson (BD Immunocytometry Systems, San Jose, CA, USA) and Coulter (Beckman Coulter Inc., Fullerton, CA, USA) hold the major market shares with their FACS and EPICS flow cytometry systems. Smaller competitors are Partec GmbH (Münster, Germany) with the PAS multiparameter laser and arc lamp flow cytometry system, Cytomation Inc. (Fort Collins, CO, USA ) with the MoFlo, a top grade 3 laser, 12 parameter high speed research sorter, and Optoflow AS (Oslo, Norway), a relative newcomer aiming specifically for the low cost side with the small, portable all solid state Microcyte flow cytometer. No recent information was found on the Cytoron Absolute flow cytometer (Ortho-Clinical Diagnostics, Raritan, NJ, USA). BioRad discontinued their arc lamp based Bryte HS flow cytometer. Not a flow cytometer, but very interesting is the LSC microscope-slide based laser scanning cytometer from Compucyte (CompuCyte Corporation, Cambridge,
MA, USA). None of these instruments is particularly designed for marine and aquatic research. It seems in practice that aquatic scientists have to explore changing the main characteristics of their standard instruments from medicine to plankton research, e.g. to find the optimum optical filters and combinations and to enhance the signal/noise-ratio as far as possible. However, even if a cheap and useful instrument would generate a boost in flow cytometer sales in the aquatic research field, the resulting market still would remain an order of magnitude smaller as compared with the biomedical market. It is not likely therefore that a dedicated instrument for the aquatic market will be released soon by these existing manufacturers.

The answers on instruments used in the survey concerned in total 30 instruments more or less regularly used by the institutes for phytoplankton analyses. Most frequently used are the instruments from Becton Dickinson (14 instruments with 5 FACSort and 4 FACS Calibur instruments) and Coulter Electronics (8 instruments). Some no longer built instruments are still in use such as a Bruker instrument (related successor by Bio-Rad now). Some inhome modified machines and completely dedicated instruments are used (Table 1). About 10 institutes operate more instruments, with a relative new instrument for routine work and cruises and an older instrument still in use for back-up, and experimental work or modifications.

\section{Limitations and pitfalls with phytoplankton samples, dedicated instruments, methodology}

Cells may be affected by fluid acceleration, electrical shock and most importantly, light shock in flow cytometers, possibly influencing subsequent analyses (Rivkin et al., 1986; Haugen et al., 1987). The instrument performance in turn may be impaired by the specific properties of aquatic samples. Low concentrations may require either preconcentration which deteriorates the sample composition, or pushing the sample flow rate to the max, leading to less accurate measurements.

Almost all participants of the survey considered the small sample volumes processed by flow cytometers a bottleneck. With low cell concentrations in natural samples, relatively large sample volumes should be analysed in order to get an acceptable statistical count. This is time consuming in standard machines: $2 \mathrm{ml}=$ around 25 minutes using the FACSCalibur. In addition, as diversity increases, the 
TABLE 1. Instruments and set-up used among the survey group.

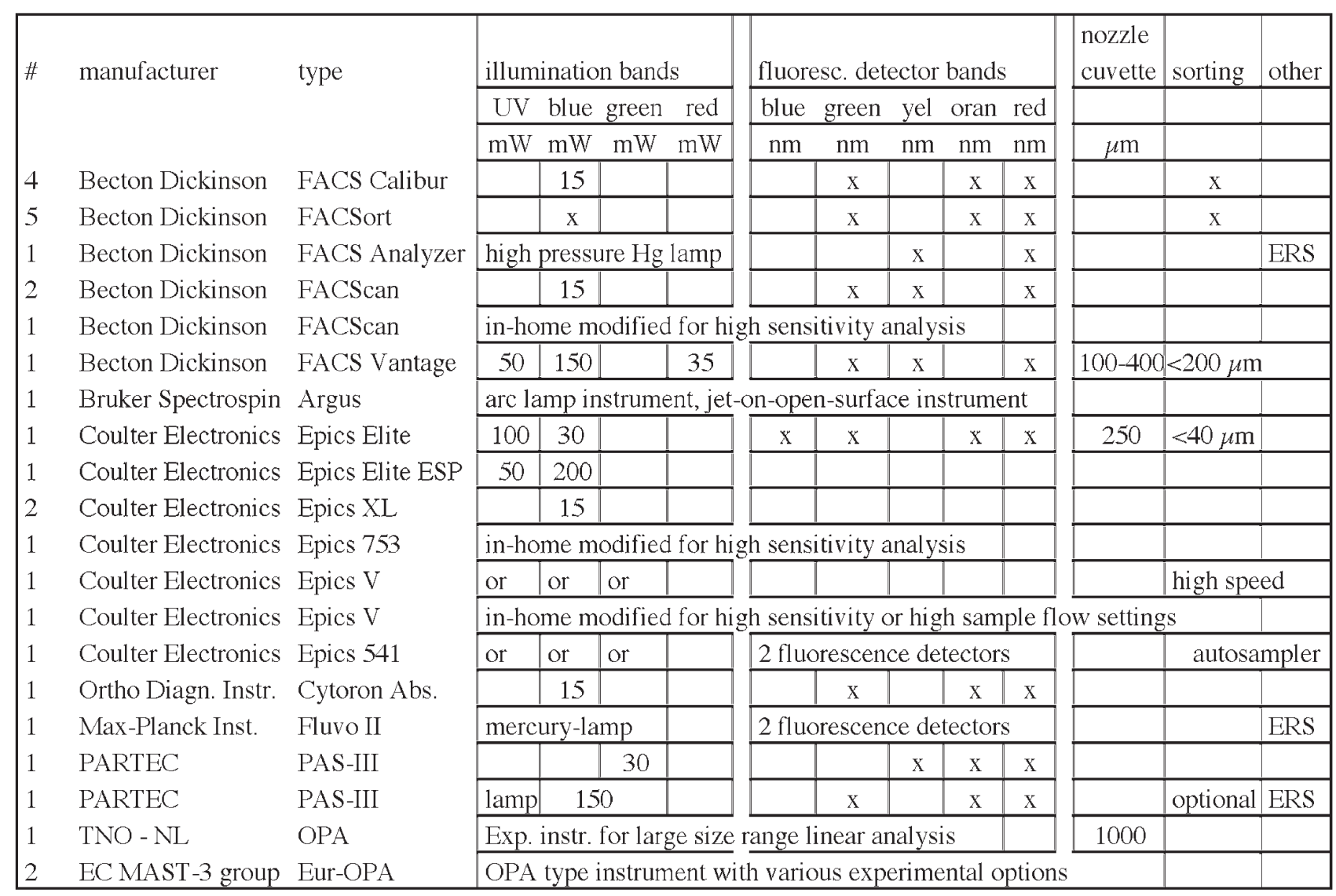

\# total nr. of instruments in mini-survey group

number of measured particles per sample has to increase accordingly for proper statistical analysis of the less abundant species. Typically the cells larg-

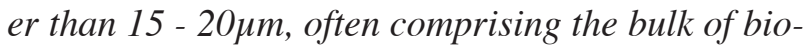
mass in eutrophic coastal environments, are relatively rare.

Standard instruments have limited particle size ranges, with upper limits of typically 30 to $150 \mu \mathrm{m}$. Large(r) particles result in system clogging or 'merely' loss of data quality. Examples of the latter are selectivity against large particles owing to small orifices and tubes in the fluid system or 'dead spaces' where large particles settle out. Particles may exceed the size of the optical sensing zone of the instrument, their electronic signals may exceed the proper range, a source of artifacts such as peak height sensing with particles longer than the height of the laser focus (Peeters et al., 1989) or time-offlight analysis of filamentous species. Big particles slow down the fluid in a cuvette (about 20\% for a particle half the channel diameter). Long fragile particles may break upon entering the flow channel, where velocity gradients are highest. Other limitations are insufficient analytical power for the wealth of cell and colony shapes, or insufficient sensitivity for the small aquatic microorganisms. A very high concentration of small particles, including those below the detection limit, may cause an upward drift of the electronic 'background signal'. This may occur with flow cytometry of sea water viruses at concentrations of for instance 10 billion per liter (Fuhrman, 1999). Even a 100 times diluted, their counting rate would be between thirty and a hundred thousand per second, causing a higher background signal that could decrease the detection probability for the smallest particles, and raise the relative counts of virus doublets as reported by Marie et al. 1999.

Olson et al. (1983) and Cunningham (1990a) constructed low-cost flow cytometers for phytoplankton analysis. High-sensitivity flow cytometers for studying picoplankton were developed by Frankel et al. (1990) and Dusenberry and Frankel (1994). Hüller et al. (1991) reported on a macro flow planktometer for analysis of large marine plankton organisms ( $>100$ $\mu \mathrm{m})$. The optical plankton analyser (OPA) was 
developed for field samples (Balfoort et al., 1992a; Dubelaar et al., 1989) containing single cells and colonies, including aggregates and filaments with lengths over a millimetre, being measured by the OPA with fair linearity (Dubelaar and van der Reijden, 1995). In the subsequent EurOPA project (Dubelaar et al., 1995b), a more versatile instrument was developed with a photodetector array probing diffracted light, a pulse profile acquisition module (Cunningham, 1990b), a cytometric imaging device (Wietzorrek, 1994; Kachel and Wietzorrek, 2000) and a sorter system. Cavender-Bares et al. (1998) developed a dual sheath flow cytometer for shipboard analyses to cope with widely varying and very low concentrations of phytoplankton in the oligotrophic oceans. Chekalyuk et al. (1996) developed a prototype pump-during-probe fluorometry flow cytometer to measure the photosynthetic capacity of cells. None of these special instruments were commercially produced on a significant scale to date. Analysis algorithms for the processing of the measured data were deveoped such as various artificial neural network approaches (Boddy and Morris, 1993; Boddy et al., 1994a, b) and multi-variate statistical protocols - the quadratic discriminant analysis being fast and the canonical variate analysis being graphically useful (Carr et al., 1994, 1996).

\section{Sample handling and preprocessing}

Avoiding particle selectivity and damage to fragile particles is not trivial. Each of the sampling, subsampling, filtration, preservation, concentration, staining, storage and transportation processes are potential sources of bias or variability. Flow cytometry requires small sample volumes, but allows more samples and less sub-sampling to obtain good statistical significance. Pre-filtration of field samples prevents clogging of the instrument flow system; concentration reduces the sample volume. Both easily impair the composition of samples containing different and fragile species. For a tenfold concentration of North Sea samples, Hofstraat et al. (1990) successfully applied a combination of sedimentation and upward filtration at low suction head. Bloem et al. (1986) examined filtration and centrifugation of heterotrophic nanoflagellates. Centrifugal elutriation provides an alternative cell separation and concentration technique when large numbers of cells are required (Pomponi and Cucci, 1989). Preservation is used to preserve cell integrity and fluorescence properties for periods of months. Although fluores- cence gradually decreases in many cases, the preservation may cause an initial short term (minutes to hours) boost in fluorescence by blocking the energy transfer mechanisms in the pigments. Flow cytometers count particles, but one obtains accurate particle concentrations only if i) the sample flow is steady and calibrated and ii) if there is no unknown loss of particle counts by coincidence. Flow cytometer sample systems driven by air pressure may not be as steady and reproducable as volumetric pump driven systems. Coincidence is proportional to the particle concentration and the dead time, occuring if particles are so close in the sample stream that they are measured together (looking like a single particle with double signal intensity), or if the opto-electronic system is still busy processing the signal of the first particle and the second goes undetected: the 'dead time effect'. Particularly with more than one laser, the dead time may be significantly larger depending on the type of electronics. Whereas most aquatic field samples have low particle concentrations from a flow cytometrical perspective, cultures and bloom samples may have to be diluted. In cases of uncertainty, reliable particle counts may be obtained by adding a known amount of fluorescent calibration beads to each sample, and to correct the cell counts for the number of detected beads. The beads can also serve as a signal intensity and/or quality reference.

The survey showed that the general working principle is to try to analyse the samples in as close to natural state as possible. Preconcentration was not mentioned, prefractioning once. Adding calibration beads for concentration and data quality assessment was mentioned once (this was not an explicit question). Preferentially, samples are measured fresh, immediately after sampling. Logistics may make it necessary to store samples, i.e. for a few days (storage at $4^{\circ}$ in the dark). This applies for the analyses done during cruises, and samples collected from shore or on short cruises. Small and fragile cells suffer also from these short periods of storage and may disintegrate. Light scatter properties will be influenced, as well as chlorophyll-a fluorescence. Fixatives used are based on what is used in microscopy and include formaldehyde (mentioned 4 times), paraformaldehyde (mentioned 5 times), glutaraldehyde (mentioned 6 times) and sometimes combinations. Lugol was not mentioned since it deteriorates fluorescence. Long time storage predominantly is in liquid $N_{2}$, in combination with $1 \%$ glutaraldehyde fixation after Vaulot et al. (1989). 
This method works well with picoplanktonic populations. Troussellier et al. (1995) examined effects on bacterioplankton and picophytoplankton. Larger and more fragile cells can be lost to an important extent however, and show variation of chlorophyll fluorescence. A possibility for improvement would be the addition of cryoprotectant (Lepesteur et al. (1993), although both optical properties and cell numbers could not be preserved well. A protocol with $0.1 \%$ to $0.5 \%$ paraformaldehyde (methanol-free) and storage at $4^{\circ}$ was developed at JRC-Ispra (Premazzi et al., 1992). Higher concentrations of paraformaldehyde increasingly impaired the results. Staining cells requires extra steps like permeabilization and washing. Recently, detailed protocols for flow cytometric enumeration of phytoplankton, bacteria, and viruses in marine samples (Marie et al., 1999), as well as for DNA/RNA analyses of phytoplankton, were published (Marie et al., 2000).

\section{MEASURED PARAMETERS}

\section{Light scatter}

The light scatter of particles is measured parallel to the laser beam: the forward or low angle scattering, and perpendicular to this: the side scattering. Simple dependence on for instance particle diameter or volume is restricted to limited classes and size ranges of particles. The highest scatter intensities are at small (low) scattering angles. Significant differences exist between small particles as for instance bacteria and larger particles as for instance ciliates. The intensity of the light scattered by the bacteria drops 3 orders of magnitude with increasing angle, whereas the light scattered by the ciliates drops 6 orders of magnitude. The measured forward light scatter depends mostly on the overall cell cross section and not so much on smaller structures, whereas the side scatter is dominated by the small internal and external structures of the particles. Internal micro structures such as light absorbing pigments and intracellular gas vacuoles may have significant effects on the forward light scatter signal, however, caused by their effect on the global refractive index of the small and medium sized cells (Dubelaar et al., 1987). The side scatter may yield the most straightforward relation (proportional to particle cross section) for particles of low refractive index, sized from about $1 \mu \mathrm{m}$ upward (Morel, 1991), but is known to be very sensitive to small cellular structures which cause large variation in the data. Whereas forward light scatter is a good measure for cell volume with very small particles $\left(<0.6 \mu \mathrm{m}^{3}\right)$ as shown by Koch $e t$ al. (1996), the forward light scatter is linearly proportional to cellular cross section only for optically large cells (tens of microns diameter and/or highly absorbing), and shows a fluctuating behaviour at intermediate sizes. In the EC MAST project AIMS (developing flow cytometry technology for identification of microbial cell populations and determination of their cellular characteristics- Geider et al., 1998; Jonker et al., 2000), algorithms are being developed to translate flow cytometric light scatter signals to size spectra. Under conditions, size and refractive index of marine particles can be measured (Ackleson and Spinrad, 1988, Spinrad and Brown, 1986). Dilution (osmosis), chemical fixation and/or staining as well as cell damage cause changes in forward light scatter signatures (Ackleson et al., 1988; Navaluna et al., 1989). Ratios of intensities at different angles can be used for sizing bacteria (Koch, 1986). With azimuthally resolved forward light scatter measurements, typical cell shape information may be obtained (Buonaccorsi and Cunningham, 1990; Cunningham and Buonaccorsi, 1992; Forrest, 1985; Premazzi et al., 1989). Smart wiring of a 25 pixel photodiode array, reduces to only 4 measured numbers per particle for symmetry and size information (Dubelaar et al., 1995b). As the laser light is linearly polarized, depolarization measurements can be implemented also relatively simply, to probe isotropic cell structures. Olson et al. (1989) used polarization properties of forward scattered light in addition to other parameters to discriminate eukaryotic phytoplankton cell types. Particularly, the coccolithophores depolarized forward scattered light. Direct measurements of particle absorption are very difficult with flow cytometers, and no such possibilities were reported. Beam attenuation (axial light loss) can be measured with flow cytometers, but this parameter is dominated by light scatter (Eisert, 1979). Many flow cytometers measure the duration of the pulses, which is a good measure for particle length if scatter pulses are used. Electrical resistance sizing (Coulter volume) is optional on a few instruments.

\section{Endogenous fluorescence}

Pigment fluorescence, the major component of endogenous fluorescence, is used for quantification of photosynthetic capacity, biomass and cell size 
(Chisholm, 1992), and identification of cellular pigment composition type. Absorbed photons generate higher excitation stages in the chlorophyll antenna pigments, from which photosynthesis is driven or by-products are generated such as heat or emission of lower energy light, fluorescence. One of the key problems in fluorescent diagnostics of photosynthetic organisms is to distinguish the contributions of constant and variable fluorescence components, because the first one contains information on the efficiency of exciton migration through the light harvesting antenna, while the second one reflects the state of PS II reaction centres and the electron-transport chain (Chekalyuk et al., 1992). At low light conditions, photosynthesis competes efficiently with fluorescence and fluorescence is low (constant fluorescence). The light intensity in flow cytometers is very high, but the passage time of the particles is extremely short (a few microseconds). The question is to what extent the variable fluorescence rises during the short passage time of the cell through the laser beam. With double or triple beam cytometers, the cell has to travel some time between the laser beams, and effects may be quite different at the down stream laser foci. Studies (Ashcroft et al., 1986; Neale et al., 1989; Xu et al., 1990) on flow cytometric fluorescence origin did not provide coherent results. Another approach is to chemically force chlorophyll fluorescence with DCMU (Furuya and $\mathrm{Li}, 1992$ ) for evaluating photosynthetic rates of natural populations. At very high photon densities such as in focused laser beams, "exciton annihilation' or photo-bleaching may reduce fluorescence yield (Chekalyuk et al., 1992; Van den Engh and Farmer, 1992). Another question is whether the amount of absorbed quanta is (dis)proportional to the amount of intracellular pigment owing to the self shading effect, also called packaging effect (Duysens, 1956). At the small size range the packaging effect is not significant; Kerker et al. (1982) showed a linear relation between fluorescence and size of small calibration beads. Natural chlorophyll absorbs light more efficiently, and obviously phytoplankton cells may be much bigger. Sosik et al. (1989) showed that analyses of Hymenomonas carterae and Amphidinium carteri are influenced by the packaging effect. Calibration is required for accurate use of fluorescence as a size indicator (Legner, 1990). Flow cytometric 'pump and probe' analysis was demonstrated by Olson and Zettler (1995). The low laser power required to measure the constant fluorescence part, impaired the analysis of small cells.
Better results were obtained with a so-called 'pump during probe' technique and using an infrared laser for particle detection to preserve the dark adapted state of the particles (Olson et al., 1996; Chekalyuk et al., 1996). The intensities used for pump and probe are orders of magnitude smaller than used in the studies mentioned above. The conclusion seems justified that more investigation of fluorescence rise times in the microsecond area, at a range of controlled flow cytometric illumination conditions, including estimation of packaging and annihilation effects, is required for a better understanding of these phenomena.

The total chlorophyll fluorescence, obtained by adding the individual particle fluorescence values, correlates well to spectrophotometrically analysed fluorescence per volume of sample (Hofstraat, 1991; Jonker, 1995). Especially for larger cells and colonies, these measurements require a dedicated optical measuring system like in the OPA as was shown for natural Microcystis colonies (Dubelaar and van der Reijden, 1995a). Based on this relationship the contributions of different groups of algae to 'biomass' can be assessed, which give more valuable information than counting of cells and colonies of different size alone. The combination of data on concentration, species and group discrimination and quantitatively measured chlorophyll fluorescence makes it possible to estimate the contribution of different species and groups to the total phytoplankton biomass. In vivo phytoplankton pigments have broad and overlapping excitation and emission characteristics, but the choice of laser wavelength and detection band influences the fluorescence measurement efficiency for a certain pigment. Fluorescence emission and excitation characteristics have been demonstrated as tools to classify groups such as cyanobacteria, cryptophytes, chlorophytes and prasinophytes, bacillariophytes and dinophytes based upon spectrally similar accessory pigments within these groups (Yentsch and Yentsch, 1979; SooHoo et al., 1986; Hilton et al., 1989; Hofstraat et al., 1990, 1991, 1994). Olson et al. (1989) simultaneously used Coulter-volume, intensity and polarisation of forward scatter, right-angle scatter, and fluorescence. From 26 laboratory cultures, the two cryptophytes and the rhodophyte, the coccolithophorids, and chlorophytes could be distinguished from others. Instead of fluorescing themselves, accessory (antenna) pigments rather increase chlorophyll-a fluorescence by energy transfer, the exception being phycocyanine and phycoerythrine 
containing species. Therefore, excitation spectra probe the spectral properties of pigments capable of energy transfer to chlorophyll a (Owens, 1991). This could encourage the application of flow cytometers with three or more excitation beams. These instruments are the most complex, unfortunately, especially the electronic timing circuitry which correlates the data from one cell, coming from three lasers. Artificial neural net analysis (Boddy et al., 1994a; Wilkins et al., 1994, 1996) showed that 2040 species can be sufficiently discriminated based on endogenous fluorescence and light scatter alone, but also showed that discrimination by this technique is not primarily based on taxonomic group identification.

\section{Exogenous fluorescence}

There are several options to extent analysis of phytoplankton by staining specific components of the cell. These fall apart in A: very specific but normally nonquantitative techniques in order to discriminate species and $\mathrm{B}$ : techniques for quantitative analysis of various constituents and physiological conditions of cells like DNA content. The dye can be fluorescent or the product of the dye and the cellular component of interest may be fluorescent. Except for the membrane binding dyes, the dyes have to enter the cell to interact with their goal substances. This can be used as a diagnostic technique for estimation of membrane integrity, otherwise the membranes have to be perforated to let the dye in (electroporation technique is described by Berglund and Starkey, 1991). An example is the use of propidium iodide for live/dead cell discrimination. Cytochemical stains are used to stain protein, DNA, RNA, lipids and membranes. Hull et al. (1982) presented staining techniques for nuclear DNA in algae. Schäfer et al. (1996) applied three-laser flow cytometry for simultaneous measurement of photosynthesis pigments and protein content using FITC of phytoplankton populations in lakes and rivers. Edvardsen and Vaulot (1996) used cell size and relative DNA content for ploidy analysis of Prymnesiophyceae spp. González-Gil et al. (1998) used flowcytometric measurement of ELF (enzymelabeled fluorescence), a new insoluble fluorogenic substrate for alkaline phosphatase to probe the phosphorus (limitation) status of individual cells. The sensitivity of flow cytometers allows the detection of very small quantities of fluorescence, down to a level of a few thousand fluorescent molecules.
This allowed the development and application of immunochemical labelling techniques. Double staining allows the assessment of more than one property at the same time, e.g. the double staining of bacteria with a DNA and a protein stain to monitor cell volume as a function of cell cycle (Steen $e t$ al., 1982). Zubkov et al. (1999) developed a flow cytometric assay for measuring protein content of marine planktonic bacterial cells using SYPRO staining. Advances in fluorescent probe technology offer realistic approaches for direct cell identification, viability assessment and responses to environmental changes using basic, single light-source flow cytometers (Porter et al., 1997). Jonker et al. (2000) gives an overview on the use of fluorescent probes in aquatic ecology.

\section{Immunotechniques}

An early overview on quantitative immunofluorescence in flow cytometry and related staining techniques was given by Visser et al. (1978). Ward and Perry (1980) presented an immunofluorescent assay for the marine ammonium-oxidizing bacterium Nitrosococcus oceanus. Clones of marine chroococcoid cyanobacteria were analysed by Campbell et al. (1983) using immunofluorescence. Antibodies to eukaryotic cells (to probe pigment types and/or cell wall composition) were presented by Shapiro et al. (1989) and Campbell et al. (1989). Antibodies were found to various cellular molecular constituents (Yentsch, 1981; Yentsch et al., 1988). Flow sorting gated on forward light scatter and FITC labelled anti-Cryptosporidium is being used in water quality analysis as a quantitative preconcentration method, which allows routinely screening of hundreds of litres of water for Cryptosporidium oocysts (Vesey, 1994). The antibody is not $100 \%$ specific, but the highly infectious oocysts are counted microscopically from the sorted fractions much quicker than before, without enrichment. Vrieling and Anderson (1996) and Vrieling et al. (1995, 1996, 1997), showed that antisera against purified cell walls and against extruded trichocystal cores of the organism, allow immunofluorescent detection in flow of the dinoflagellates Prorocentrum micans, Gyrodinium aureolum and Gymnodynium nagasakiense. Simon et al. (1997) identified the toxic algae Chrysochromulina and Prymnesium species using fluorescent or chemiluminescent oligonucleotide probes. For a review of immuno flow cytometry, see Peperzak et al., 2000). 


\section{DNA and RNA quantification}

DNA can be fluorescently stained with many fluorochromes. Flow cytometric determination of phytoplankton DNA in cultures and field samples was reported by Yentsch et al. (1983b), Bonaly et al. (1987), and Boucher et al. (1991) from cultured samples stained with DAPI, which can be excited with UV light. The DAPI-DNA fluorescence was related to cell DNA content over almost 4 orders of magnitude. In natural populations, the fraction of particulate DNA contained in photosynthetic picoplankton could be computed. Currently, a new series of fluorochromes are being applied for highresolution DNA quantification by flow cytometry. Among these are TOTO-1, SYBR-Green, Picogreen, SYTOX green (Marie et al., 1996; Li et al., 1995; Marie et al., 1997; Guindulain et al., 1997) and YOYO-1 (Jochem and Meyerdierks, 1999). They have major advantages over previously used dyes like DAPI and propidium iodide. They can be excited at $488 \mathrm{~nm}$, the standard laser wavelength for most benchtop instruments, and result in green fluorescence which hardly interferes with pigment fluorescence (Chl-a), and are specific for double stranded DNA, instead of also staining RNA (Pan and Cembella, 1996; Pan et al., 1999). A comparison of seven blue nucleic acid SYBR and SYTO series dyes for flow cytometric enumeration of bacteria in aquatic systems by Lebaron et al. (1998a) showed that SYBR-II and SYTO-9 are the most appropriate dyes for bacterial enumeration in nonsaline waters and can be applied to both live and dead bacteria, whereas SYBR-II is more appropriate than SYTO dyes for seawater samples. SYTOX Green however underestimates the fraction of dead bacterial cells within starved populations (Lebaron et al., 1998b, see also Gasol and del Giorgio, 2000) and its application to natural samples should be considered with caution. Veldhuis et al. (1997a) established a nice data set of DNA content of individual phytoplankton species. They also showed that there is a good correlation between DNA content, as measured with these dyes, and phytoplankton biomass. This correlation is better than the correlation between biomass and Chl-a fluorescence which is influenced significantly by the light history of the cells. The next important step would be to transfer this to field samples. The ratio between RNA and DNA can be used to discriminate actively growing cells from resting cells. The application of e.g. SYTO 13 allows assessment of bacterial abundance (Del Giorgio et al., 1996; Gasol and del Giorgio, 2000); SYBR Green allows for discrimination between heterotrophic bacteria and autotrophic Prochlorococcus cells (Marie et al., 1997). Binder and Liu (1998) examined the relationship between growth rate and rRNA content in a marine Synechococcus strain by a combination of flow cytometry and whole-cell hybridization and found that both these methods correlated well in determination of total cellular RNA, which varied in a similar manner as growth rate, supporting the notion that measurements of cellular rRNA content might be useful for estimating in situ growth rates in natural Synechococcus populations. Brussaard et al. (1999) showed that flow cytometry can be a useful tool to discriminate between virus infected and noninfected phytoplankton cells by detection of de novo synthesis of viral DNA and possible digestion of host DNA.

\section{Cell cycle analysis}

Whereas the connection between cell division and the need for metabolites and photosynthates is obvious, the mechanism of light acting upon cellular DNA synthesis regulation is not so clear (Yee and Bartholomew, 1988). Flow cytometric DNA analysis is a helpful tool in this respect (Chisholm et al., 1986). Brzezinski et al. (1990) examined the role of silicon availability on cell-cycle progression in marine diatoms. Examination of DNA histograms allowed the localization of the effect of silicon deprivation in terms of progress through $\mathrm{G} 1, \mathrm{~S}$, and G2+M phase. Yee and Bartholomew (1988) studied light regulation of the cell cycle in Euglena gracilis bacilaris. Euglena grown under phototrophic conditions are easily synchronized to a $12 \mathrm{~h}$ light- $12 \mathrm{~h}$ dark regime. By inoculating stationary phase, nondividing cells into fresh media and exposing the diluted cells to either light or darkness, it was observed that initiation of DNA synthesis for the cell division cycle is light dependent. Commitment to the cell cycle requires exposure to more than $6 \mathrm{~h}$ of light, supposedly to allow the accumulation of an initiating factor that will enable DNA synthesis to begin. Flow cytometry analysis showed that once cells are committed to the cell cycle, they complete the cycle in the dark, so mitosis is a light-independent step. Lefort et al. (1987) used DNA flow cytometry to study cell cycle blockade of vitamin B12-starved cells. Binder and Chisholm (1990) studied the relationship between DNA cycle and growth rate in 
Synechococcus-sp strain PCC 6301. This cyanobacterium was shown to contain multiple chromosome copies even at very low growing rates. Evidence was found for asynchronous initiation of DNA replication. Vaulot et al. (1995) elegantly showed that DNA replication occurred in the afternoon by analyzing Prochlorococcus in samples from different depths using Hoechst 33342. The next step in in situ growth rate analysis is to combine specific detection of single species with cell cycle analysis. Specific detection can be done with in situ hybridization or with monoclonal antibodies. Peperzak et al. (1998) showed that flow cytometry can be used for the analysis of the dial DNA cycle.

\section{Identification of species and groups using ribosomal RNA-targeted nucleic acid probes}

The use of ribosomal RNA probes for flow cytometric identification of both individual species and taxonomic groups is very promising. Parts of the ribosomal RNA sequences were highly conserved during evolution and the differences in rRNA sequences correlate well with evolutionary relations. Fluorescently labelled rRNA probes are relatively small and penetrate easily in fixed cells (Amann et $a l ., 1990)$. There they hybridize specifically to the target sequences. This is very useful for fluorescent in situ hybridization (FISH), a process which can be visualized using both microscopy and flow cytometry. Recently, the application of rRNA probes for detection of phytoplankton species and groups was established (Lim et al., 1993; Simon et al., 1995; Knauber, 1996; Rice et al., 1997; Partensky et al., 1997, Jonker et al., 2000). Lange et al. (1996) have shown that target regions specific for the class Prymnesiophyceae and the genus Phaeocystis (Hariot) Lagerheim could be identified from $18 \mathrm{~S}$ rRNA coding regions, and two complementary probes were designed. Detection of whole cells hybridized with these probes labelled with fluorescein isothiocyanate (FITC) was difficult using epifluorescence microscopy because autofluorescence of the chlorophylls seriously interfered with the fluorescence of the probes. In contrast, flow cytometry proved very useful to detect and quantify the fluorescence of the hybridized cells. Hybridization conditions were optimized, especially with respect to formamide concentration. Both probes were tested on a large array of both target and non-target strains. Positive and negative controls were also analysed. Specificity was also tested by adding a competing non- labelled probe. Whereas probe PHAEO01 seems to have good specificity, probe PRYMN01 appeared less specific and must be used with stringent positive and negative controls. A large number of rRNA sequences has already been analysed and is available through internet. The use of a $18 \mathrm{~S}$ rRNA probe for detection of Cryptosporidium was established by Vesey (1996). This allows for a very quantitative technique for analysis of Cryptosporidium.

Monoclonal antibodies and/or other molecular probes are used for aquatic bacteria and phytoplankton analysis by 6 of the 19 survey institutes; 4 other institutes say they will in the future.

Applications: The survey institutes all carry out species or (pigment or taxonomic) group identification in field samples by flow cytometry, mostly taxonomic groups based on pigment analysis, such as prochlorophytes, cyanobacteria, (sub-types of) Synechococcus e.g. phycocyanin- and phycoerythrin-rich Synechococcus spp., cryptophytes, dinoflagellates and diatoms. Furthermore, eukaryotic picoplankton (three types of picoeukaryotic algae), and nanoplankton can be identified. Size is used by one institute as extra indicator to identify 6 groups in North Sea waters: Phaeocystis (only blooms), Mesodinium, Rhodomonas, Dinoflagellates and Diatoms <25 $\mathrm{\mu m}, 25-100,>100 \mu \mathrm{m}$. Gymnodinium mikimotoi is being identified using monoclonal antibodies. Heterotrophic bacteria are distinguished with DNA stains, while some molecular probes are also used. Applications mentioned included

- Phytoplankton photophysiology, ecophysiology, toxicology, metabolic activity (3 times)

- The relationship between phytoplankton, bacteria and detritus (4 times), bacterial sorting to discriminate active cells (twice), size distribution of bacteria ( 2 times)

- Grazing impact studies (6 times), food selectivity of cockles

- Isolation of strains(e.g. gonyaulacoid cells) from natural populations by sorting (twice), isolation of diatoms transformed with GFP gene

- In situ hybridization with taxon-specific rRNA probes

\section{Phytoplankton abundance}

Basic characterisation of particles by flow cytometry can be done on a routine basis, such as a division in organic and inorganic particles, living and nonliving organic particles, e.g. Moreira-Turcq 
and Martin (1998). Flow cytometry allows rapid phytoplankton counting and sizing based on the chlorophyll fluorescence, and limited identification of taxonomic groups and species ( $\mathrm{Li}$ and Wood, 1988; Yentsch and Yentsch, 1979; Yentsch and Pomponi, 1986; Olson et al., 1989; Hofstraat et al., 1990, 1994; Blanchot and Rodier, 1996; Binder et al., 1996; Li, 1997; Veldhuis and Kraay, 1990; Wood et al., 1985). Clearly, pigment analysis using flow cytometry is much cruder than, for example, HPLC, but main pigments can be studied with success (Olson et al., 1990; Hess et al., 1996). Using the specific, immuno- and molecular probes enables the determination of intracellular substances such as lipid droplets in diatoms and toxins in dinoflagellates, and allows more specific species/group characterisation and discrimination (Bloodgood et al., 1987; Simon et al., 1994, 1995; Rao et al., 1991). Biodiversity of unicellular pico- and ultraplanktonic eukaryotes was studied by Chrétiennot-Dinet and Courties (1997). As very little is known about sexuality and life-cycles of these tiny algae, a whole set of complementary techniques including flow cytometry appears necessary to ensure a reliable assessment of identification and diversity. Gasol et al. (1999) estimated bacterial abundances with epifluorescence microscopy methods and with flow cytometry (SYTO13) and found good correspondence between microcosm experiments and coastal Mediterranean water. Flow cytometry is likely to prove useful for detecting the low-level occurrence of harmful species, giving early warning of the probability of bloom development. It enables monitoring of bacteria in seawater (Button and Robertson, 1989, 1990; Robertson and Button, 1989; Wiebenga et al., 1997; Zubkov et al., 1998). Flow cytometry allows higher sampling frequencies, important for the execution of ship transects, depth profiles and also incubation experiments to study the distribution and composition of phytoplankton populations, including diurnal variations (Tarran and Burkill, 1993; Burkill, 1987; Olson et al., 1985; Li, 1989; DuRand et al., 1994; Jacquet et al., 1998). Flow cytometry has also been used in all Joint Global Ocean Flux Studies (JGOFS) to date, particularly studies of the dynamics and distribution patterns of pico-phytoplankton, ultra-phytoplankton, and bacteria (Binder et al., 1996; Detmer and Bathmann, 1997), with diel cycling and biomass assessed from flow-cytometer cellular light scatter observations (Blanchot et al. 1997; Gin et al., 1999, respectively), the importance of Prochlorococcus to commu- nity structure (Campbell et al., 1994) and the effect of environmental forcing on microbial community structure (Campbell et al., 1998), investigations in the microbial food web structure in the Arabian Sea by Garrison et al. (2000), revealing a correlation between dominance of large phytoplankton, primarily diatoms, and the seasonal maxima of mass flux during the SW Monsoon. Landry et al. showed in 1996 that, while picoplankton account for most of the chlorophyll biomass and primary production in the central equatorial Pacific, their abundances and distributions are relatively stable and conservative while other populations, such as diatoms, respond more dramatically to environmental forcing. Other JGOFS missions included microzooplankton grazing in the central equatorial Pacific (Constantinou et al., 1995) and the Arabian Sea (Reckermann and Veldhuis, 1997), and flow cytometry based studies of energetics and growth kinetics of a deep Prochlorococcus spp. population in the Arabian Sea (Johnson et al., 1999), populating almost exclusively the detected secondary fluorescence maxima (SFM).

\section{Ecology and physiology}

Flow cytometers can play an important role in the experimental verification of ecological models (Campbell et al., 1997). These models include spatial and/or temporal distributions of species and groups (Olson et al., 1990; Partensky et al., 1996; Shimada et al., 1993, 1995; Tarran et al., 1999; Vaquer et al., 1996; Vaulot et al., 1990; Zubkov et al., 1998, 2000), size distributions and population dynamics, but can also consider flow cytometrically probed status of life cycle (Binder and Chisholm, 1995; Brzezinski et al., 1990; Van Bleijswijk et al., 1994; Van Bleijswijk and Veldhuis, 1995; Green et al., 1996; Vaulot and Marie, 1999) allowing growth rate determination (Veldhuis et al., 1997b), and physiological properties of the cells such as metabolic activity (Dorsey et al., 1989; Jellet et al., 1996; Del Giorgio et al.,1997). Shalapyonok et al. (1998) reported ultradian growth (faster than 1division per day) observed for the widespread marine prokaryote Prochlorococcus, even though cell division was strictly phased to the light-dark cycle. Correlation of metabolic with flow cytometric characteristics is a feasible means of investigating the heterogeneity of phytoplankton metabolic state in the marine environment. The response to changes in light conditions (Armbrust et al., 1989, 1990; Gerath and 
Chisholm, 1989; Vaulot et al., 1986), nutrient availability (Trousselier et al., 1997; Vaulot et al., 1987; Veldhuis and Kraay, 1993; Graziano et al., 1996; Zettler et al., 1996; Timmermans et al., 1998; Lebaron et al., 1999) and kinetics (Button and Robertson, 2000) can be assessed. Lipschultz (1995) measured nitrogen-specific uptake rates of marine phytoplankton by flow cytometry. Huisman et al. (1999) elegantly used flow cytometry in competition experiments in order to validate models describing competition for light using fresh water species from eutrophicated systems. Other applications include the investigation of microbial food webs (Cowles et al., 1988; Cucci et al., 1985, 1989; Gerritsen and Sanders, 1987; Lesser et al., 1991; Sellner et al., 1994; Hansen et al., 1996; Reckermann and Veldhuis, 1997) and the evaluation of the effect of toxic substances on algae (Gala and Giesy, 1990, 1994), or toxic algae on zooplankton (Turner et al., 1998). Boelen et al. (2000) used flow cytometry for phytoplankton species composition and size analysis in a study of ultraviolet-B (UVB) radiation induced DNA damage in picoplankton assemblages in the tropical Atlantic Ocean, indicating that radiation damage is size dependent, and mean received doses are reduced by wind-induced mixing. Mostajir et al. (1999) found retardation of cell division, inhibition of photosynthesis and cell size enlargement of Prymnesiophyceae provoked by UVB. Waite et al. (1995) measured sugar-containing compounds on cell surfaces of marine diatoms with flow cytometry using concanavalin A. Measurements of effects of iron stress on chromatic adaptation by natural phytoplankton communities in the Southern Ocean by Van Leeuwe et al. (1998) showed that iron did affect the pigment composition, but the efficiency of electron transfer. Reed et al. (1999) followed changes in the neutral lipid content of actively swimming zoospores of the palm kelp Pterygophora californica by flow cytometry using the fluorescent stain Nile Red. A flow cytometric approach to assess the environmental and physiological status of phytoplankton was presented by Demers et al. (1989). The analysis of natural phytoplankton populations can indicate changes in water quality and environmental stress (Olson and Chisholm, 1986; Olson et al., 1986; Parpais et al., 1996), starvation conditions (Joux et al., 1997), and contamination by anthropogenic inputs (Berglund and Eversman, 1988; Bonaly-Cantarel, 1988; Firth et al., 1994; Cid et al., 1996, 1997; Cavender-Bares, 1999; Faber et al., 1998; Franqueira et al., 1999).

\section{Size and biomass}

Many biological processes involved in biogeochemical fluxes, e.g. production, respiration, grazing, sinking, aggregation, are linked to the biomass and size distributions of bacteria (Button and Robertson, 1989, Robertson et al., 1998) and phytoplankton (Rodriguez and Li, 1994, Gin et al., 1999). For that reason the development of flow cytometric techniques for particle size determination was advocated by Legendre and Le Fevre (1991). Shipboard based instruments allow fast assessment of abundance and biomass variations (Burkill, 1987; Borsheim et al., 1989; Zohary et al., 1998; Zubkov et al., 1998, 2000), to probe three dimensional patchiness dynamics such as in eddies (Tintore et al., 1998). Buck et al. (1996) estimated living carbon biomass of microplankton, nanoplankton and picoplankton using a combination of dual beam flow cytometry and epifluorescence microscopy. The contribution of picophytoplankton to biomass, productivity and community structure was the subject of various studies using flow cytometry (Li, 1994, 1995; Charpy and Blanchot, 1998, 1999; Liu et al., 1997; Gasol et al, 1997, 1999). Pichard et al. (1997) used flow cytometry to show the utility of groupspecific gene probes for examining the relation of active phytoplankton community structure to the fixation of inorganic carbon. Weisse and Kirchhoff (1997) measured feeding rates and food selectivity of the heterotrophic freshwater dinoflagellate Peridiniopsis berolinense by flow cytometry and other techniques. Bougrier et al. (1997) used flow cytometry to study preingestive selection of different microalgal mixtures in Crassostrea gigas and Mytilus edulis. A rapid cytometric method assessing the distribution of ingested bacteria in nanoflagellates was presented by Bratvold et al. (2000), investigating grazing behaviour of cultures of Rhynchomonas nasuta and Paraphysomonas vestita. Their results suggest a heterogeneous population composed of subgroups of flagellates with different grazing rates, although the specific biological implications of the statistical models used with regard to the number of flagellate subgroups remain to be proven. Grazing was also studied by Christaki et al. (1999) who found that Prochlorococcus may be less subject to ciliate predation than Synechococcus, and Kenter et al. (1996) who recorded the feeding of Balanion planctonicum on the cryptomonad Rhodomonas sp. in vivo at 2-3 min intervals by flow cytometry. Vazquez-Dominguez et al. (1999) pre- 
sented some succesful flow cytometric experiments to estimate grazing rates on bacteria with fluorescently labeled tracers, and Kuipers and Witte (1999) demonstrated the use of flow cytometry to obtain significant results in a study of the impact of microzooplankton community grazing on different size classes of algae. Pile et al. (1997) studied trophic effects of sponge feeding on four types of picoplankton, and Monger et al. (1999) examined the influence of cell-surface hydrophobicity. Gin et al. (1999) studied seasonal and depth variation in microbial size spectra at the Bermuda Atlantic time series station, using dual-beam flow cytometry to generate concentration and biomass size spectra of bacteria and phytoplankton.

Almost half (8) of the survey participants carry out quantification of growth/production rates (basing on DNA / cell cycle analysis) of phyto-/bacterioplankton.

The ocean colour is a prime source of information (Morel and Prieur, 1977). Remote sensing data may be utilized in calibration and validation of hydrodynamic and ecological models, and for instance the assessment of the spatial variability of biomass within a bloom area, or on a larger scale the photosynthetic carbon fixation in the world oceans. Data interpretation depends on atmospheric correction methods and bio-optical algorithms, calibrated with locally (on site) acquired entities such as extracted chlorophyll. Calibration with 'sea truth' data on the particle level is complicated (Lewis and Cullen, 1991) but feasible, for instance for coccolithophore blooms (Holligan and Balch, 1991; Balch et al., 1992, 1993), or a bio-optical classification of sea particles (Ackleson and Robins, 1990). Although flow cytometers can measure cellular light absorption indirectly only (Perry and Porter, 1989), other entities such as fluorescence, forward and perpendicular light scatter are useful to assess particle optical properties and the relationship with the in situ light fields (Spinrad, 1984; Ackleson et al., 1993; Cullen et al., 1988; DuRand and Olson, 1996).

The general idea is, although it is obviously not a trivial matter, that flow cytometry data could be related to measurements of bulk light scatter or attenuation data measured with other instruments. Some scientific work and projects are being executed in this field currently. Some institutes compare flow cytometry data with microscopic counts and optical telemetry (shipboard SpectraScan) data from specific stations. The main advantage of the flow cytometer is the straightforward evaluation of phytoplanktonic biomass within main groups. Another aspect is that major changes in ocean colour are based on new production (hence large) species. If cytometers were to be technically tuned towards larger organisms (probably even aggregates) and larger measuring volumes they could be useful for that purpose, in addition to the importance of flow cytometry for characterising small particles.

\section{DISCUSSION}

A high potential of the technique was acknowledged by all participants of the survey. It was stated that the direct on-line estimation of phytoplankton biomass and the ability to discriminate between different phytoplankton groups allows analysis of undisturbed natural samples (growth, grazing, the spatial or seasonal evolution of populations). Also, the application of specific fluorescent stains (bound to antibodies, or as DNA probes) may provide early detection of plankton groups of special interest, e.g. toxic species. By combining auto- and artificially fluorescent properties, potential developments arise include monitoring, in situ growth rates, biomass estimation of both autotrophs and heterotrophs, ecosystem processes, physiological status of microbial assemblages such as nutritional status, viability, photosynthesis, and various stress physiology. On a broader scale, we can use a similar approach to study primary productivity, and new production in the field. Flow cytometry also carries potential for the determination of small particles such as bacteria. Besides limitations as mentioned previously, an inherent drawback of flow cytometry is that it can only differentiate particles based on their optical characteristic as seen by the PMT's. This is better than the eye for the very small cells (picoplankton), and vice versa for the larger cells. The species resolution of field samples done by flow-cytometry is far below the Utermoehl-microscopy. The expectation that this situation can improve if the lack of specific fluorescent probes is reduced was widely supported in the survey. The laborious work to establish them remains a hurdle, as well as perhaps the human factor: ecologists prefer microscopic monitoring data. With regard to reproducibility it was mentioned that there is a real need for (i) standardization of flow cytometric analysis of field samples, 
and (ii) continuous checking against other independent methods (such as microscopy).

Clearly, applications of flow cytometry in the field of aquatic sciences are numerous and expanding. It is not possible to define general requirements: shipboard analysis requires robust, easily transportable equipment; oceanography requires high sensitivity analysis of small cells; coastal and fresh water applications require a large dynamic range. Many physiological experiments and species identification using molecular techniques can be done with one or two parameters, whereas species identification based on inherent optical properties requires large numbers of independent entities measured from a single particle. Broadly used dedicated commercial equipment is not expected soon, but the general instrumental developments are promising. Data acquisition and processing gets more efficient, lasers and detectors get smaller, PC's get faster and hard discs get bigger, costs decrease. Instrument size, -operation, -costs and -reliability and data handling will not remain bottlenecks for long. Developments over a longer period will allow real-time in-situ measurements. These developments facilitated the development of the buoy based flow cytometer CytoBuoy with radiotransmission (viz. Fig. 1) to shore (Dubelaar et al., 1999; Dubelaar and Gerritzen, 2000). A submersible version will also be deployed on missions with an autonomous underwater vehicle (AUV), while Olson and Sosik (1999) developed a submersible flow cytometer without a sheath fluid system. Much effort has to be devoted to standardization of sampling and preservation and of reporting and data analysis. This also requires intercalibration of flow cytometers. Also the systematic investigation of the phenomena governing the light scatter and fluorescence of phytoplankton cells as measured flow cytometrically would contribute to a better understanding of these analysis tools. This may facilitate the intercalibration between flow cytometers and possibly the intercalibration of data from flow cytometers with remote sensing data and other 'bulk' techniques (Dubelaar et al., 1994; Geider et al., 1998). It would also support the further development and use of 'pump/probe' capabilities in flow cytometry to measure photosynthetic parameters in a single cell. If analysis of major functional groups within the phytoplankton and bacteria becomes routine, it will be possible to base timeseries on flow cytometric data, with the advantages of higher frequencies in time and space.

\section{ACKNOWLEDGEMENTS}

We thank the editors of this issue for encouraging us to write this paper, and we thank the reviewers for their valuable contribution. For responding to the survey we gratefully thank Dr. P.H. Burkill (Plymouth Marine Laboratory, United Kingdom), Dr. Raffaella Casotti (Stazione Zoologica 'A. Dohrn', Italy), Dr. Kent Cavender-Bares (Dept. of Biology, Massachusetts Inst. of Techn. USA), Dr. Claude Courties (Laboratoire d'Hydrobiologie Marine, Université Montpellier II, France), Dr. Alex Cunningham (Univ. of Strathclyde, Dept. of Physics and Appl. Physics, Scotland (UK)), Dr. Michel Denis (Centre d'Oceanologie de Marseille, France), Dr. Ken Furuya (Department of Aquatic Bioscience, University of Tokyo, Japan), Dr. Josep M. Gasol (Institut de Ciencies del Mar, Catalonia (Spain)), Dr. Hans Hoogveld (Netherlands Institute of Ecology, Centre for Limnology, The Netherlands), Dr. Frank J. Jochem (The University of Texas at Austin, USA) Dr. Ulrich Kenter (University of Konstanz, Dept. of Limnology, Germany), Dr. Philippe Lebaron (Université Pierre et Marie Curie, Observatoire Océanologique, France), Dr. William Li (Bedford Insitute of Oceanography, Canada), Dr. Youlian Pan (Inst. for Marine Biosc., National Res. Council of Canada, Canada), Dr. Falk Pollehne (Institut für Ostseekunde, Warnemünde, Germany), Dr. Marcus Reckermann (Univ. Kiel, Research and Technology Center Westcoast, Germany), Dr. Jaime Rodríguez (Dpto. de Ecologia, Fac. de Ciencias, Universidad de Malaga, Spain), Thomas Rutten MSc (National Institute for Coastal and Marine Management, The Netherlands), Dr. Marcel Veldhuis (Netherlands Institute of Sea Research, The Netherlands).

Information was used from the internet sites of Station Biologique CNRS - INSU - UPMC (www.sb-roscoff.fr) Roscoff, France; J.J. MacIsaac Facility for Indiv. Particle Anal. (www.bigelow.org); West Boothbay Harbor, Maine, USA; Institut für Meereskunde Kiel (www.ifm.uni-kiel.de) Kiel, Germany.

\section{REFERENCES}

Ackleson, S.G. and R.W. Spinrad. - 1988a. Size and refractive index of individual marine particulates: A flow cytometric approach. Appl. Opt. 27: 1270-1277.

Ackleson, S.G., R.W. Spinrad, C.M. Yentsch, J. Brown, and W. Korjeff-Bellows. - 1988b. Phytoplankton optical properties: Flow cytometric examinations of dilution-induced effects. Applied Optics 27(7): 1262-1269. 
Ackleson, S.G. and D.B. Robins. - 1990. Flow cytometric determinations of North Sea phytoplankton optical properties. Neth. J. Sea Res. 25: 11-18.

Ackleson, S.G., J.J. Cullen, J. Brown, and M. Lesser. - 1993. Irradiance-induced variability in light scatter from marine phytoplankton in culture. J. Plankton Res. 15: 737-759.

Ahscroft, RG., C. Preston, R.E. Cleland and C. Critchley. - 1986. Flow cytometry of isolated chloroplasts and thylakoids. Photochemistry and Photobiophysics 13: 1-14.

Amann, R.I., B.J. Binder, R.J. Olson, S.W. Chisholm, R. Devereux, and D.A. Stahl. - 1990. Combination of 16S rRNA-targeted oligonucleotide probes with flow cytometry for analyzing mixed microbial populations. Appl. Env. Microbiol. 56(6): 1919-1925.

Armbrust, E.V., J.D. Bowen, R.J. Olson, and S.W. Chisholm. 1989. Effect of light on the cell cycle of a marine Synechococcus strain. Appl. Env. Microbiol. 55(2): 425-432.

Armbrust, E.V., R.J. Olson, and S.W. Chisholm. - 1990. Role of light and the cell cycle on the induction of spermatogenesis in a centric diatom. J. Phycol. 26: 470-478.

Azam, F. and DC. Smith. - 1991. Bacterial influence on the variability in the oceans's biochemical state: a mechanistic view. In: S. Demers (Ed.), Particle analysis in oceanography (NATO ASI Series, G: Ecological Sciences, Vol. 27, Springer-Verlag Berlin Heidelberg.

Balch, W.M., P.M. Holligan, and K.A. Kilpatrick. - 1992. Calcification, photosynthesis and growth of the bloom-forming coccolithophore, Emiliana huxlevi. Cont. Shelf Res. 12: 1353-1374.

Balch, W.M., K. Kilpatrick, P.M. Holligan, and Terry L. Cucci. 1993. Coccolith production and detachment by Emiliania huxleyi (Prymnesiophyceae). J. Phycol. 29: 566-575.

Balfoort, H.W., Th. Berman, S.Y. Maestrini, A. Wenzel, and T. Zohary. - 1992a. Flow cytometry: instrumentation and application in phytoplankton research. Hydrobiologia 238: 89-97.

Balfoort, H.W., J. Snoek, J.R.M. Smits, L.W. Breedveld, J.W. Hofstraat and J. Ringelberg. - 1992b. Automatic identification of algae: neural network analysis of flow cytometric data. $J$. Plankton Res. 14 (4): 575-589.

Berglund, D.L. and S. Eversman. - 1988. Flow cytometric measurement of pollutant stresses on algal cells. Cytometry 9(2): 150-155.

Berglund, D.L. and J.R. Starkey. - 1991. Introduction of antibody into viable cells using electroporation. Cytometry 12(1): 64-7.

Binder, B.J. and S.W. Chisholm. - 1990. Relationship between DNA cycle and growth rate in Synechococcus sp. strain PPC 6301. J. Bact. 172(5): 2313-2319.

Binder, B.J. and S.W. Chisholm. - 1995. Cell Cycle Regulation in Marine Synechococcus. Appl. Env. Microbiol. 61(2): 708-717.

Binder, B.J., S.W. Chisholm, R.J. Olson, S.L. Frankel, and A.Z. Worden. - 1996. Dynamics of Pico-phytoplankton, Ultra-Phytoplankton, and Bacteria in the Central Equatorial Pacific. Deep-Sea Res. II 43: 907-931.

Binder, B.J. and Y.C. Liu. - 1998. Growth Rate Regulation of rRNA Content of a Marine Synechococcus (Cyanobacterium) Strain. Appl. Env. Microbiol. 64(9): 3346-3351.

Blanchot, J. and M. Rodier. - 1996. Picophytoplankton abundance and biomass in the western tropical Pacific Ocean during the 1992 El Nino year: Results from flow cytometry. Deep-Sea Res. Part I, Oceanographic Research Papers 43: 877-895.

Blanchot, J., J.-M. Andre, C. Navarette and J. Neveux. - 1997. Picophytoplankton dynamics in the equatorial Pacific: Diel cycling from flow-cytometer observations. C. R. Acad. Sci., Ser. III. Sci. Vie/Life Sci. 320(2): 925-931,

Bloem, J., M.J.B. Bär-Gilissen and T.E. Cappenberg. - 1986. Fixation, counting and manipulation of heterotrophic nanoflagellates. Appl. Environ. Microbiol. 52 (6): 1266-1272.

Bloodgood, R.A., N.L. Salomonsky and F.D. Reinhart. - 1987. Use of carbohydrate probes in conjunction with fluorescence-activated cell sorting to select mutant cell lines of Chlamydomonas with defects in cell surface glycoproteins. Exp. Cell Res. 173: 572-585.

Boddy, L. and C.W. Morris. - 1993. Neural network analysis of flow cytometry data. In: Lloyd, D. (ed.) Flow Cytometry in Microbiology, pp. 159-169. Springer-Verlag, Berlin.

Boddy, L. C.W. Morris, M.F. Wilkins, G.A. Tarran and P.H. Burkill. - 1994a. Neural network analysis of flow cytometric data for 40 marine phytoplankton species, Cytometry 15 : 283-293.
Boddy, L., M.F. Wilkins, C.W. Morris, G.A. Tarran, P.H. Burkill and R.R. Jonker. - 1994b. Techniques for neural network identification of phytoplankton for the EurOPA flow cytometer. In: OCEANS '94 OSATES: Ocean Engineering for today's technology and tomorrow's preservation. Vol. 1: 565 - 569. IEEE, New York.

Boelen, P., M.K. de Boer, G.W. Kraay, M. J.W. Veldhuis, A.G.J. Buma. - 2000. UVBR-induced DNA damage in natural marine picoplankton assemblages in the tropical Atlantic Ocean. Mar. Ecol. Progr. Ser. 193: 1-9.

Bonaly, J., M.H. Bre, M. Lefort-Tran and J.C. Mestre. - 1987. A flow cytometric study of DNA staining in situ in exponentially growing and stationary Euglena gracilis. Cytometry 8(1): 42-45.

Bonaly-Cantarel, J. - 1988. Cytophysiological and cytotoxicological studies in unicellular algae: the effects of cadmium in Euglena gracilis cells. Flow cytometry analysis suppl. Bull. Soc. Bot. Fr. Lett. Bot. 135(1): 27-40.

Borsheim, K.Y., T. Harboe, T. Johnsen, S. Norland and K. Nygaard. - 1989. Flow cytometric characterization and enumeration of Chrysochromulina-polylepis during a bloom along the Norwegian coast. Mar. Ecol. Prog. Ser. 54(3): 307-309.

Boucher, N., D. Vaulot and F. Partensky. - 1991. Flow cytometric determination of phytoplankton DNA in cultures and oceanic populations. Mar. Ecol. Prog. Ser. 71(1): 75-84.

Bougrier, S., A.J.S. Hawkins and M. Heral. - 1997. Preingestive selection of different microalgal mixtures in Crassostrea gigas and Mytilus edulis, analysed by flow cytometry. Aquaculture, 150(1-2): 123-134.

Bratvold, D., F. Srienc, S.R. Taub. - 2000. Analysis of the distribution of ingested bacteria in nanoflagellates and estimation of grazing rates with flow cytometry. Aqua. Micro. Ecol. 21: 1-12.

Brussaard, C.P.D., R. Thyrhaug, D. Marie and G. Bratbak. - 1999. Flow cytometric analyses of viral infection in two marine phytoplankton species, Micromonas pusilla (prasinophyceae) and Phaeocystis pouchetii (prymnesiophyceae). J. Phycol. 35: 941-948.

Brzezinski, M.A., R.J. Olson and S.W. Chisholm. - 1990. Silicon availability and cell-cycle progression in marine diatoms. Mar. Ecol. Prog. Ser. 67(1): 83-96.

Buck, K.R., Chavez FP, Campbell L. - 1996. Basin-wide distributions of living carbon components and the inverted trophic pyramid of the central gyre of the North Atlantic Ocean. Aqua. Microb. Ecol. 10: 283-298.

Buonaccorsi, G.A. and A. Cunningham. - 1990. Azimuthal inhomogeneity in the forward light scattered from microalgal colonies, and its use as a morphological indicator in flow cytometry. Limnol. Oceanogr. 35: 1170-1175.

Burkill, P.H. - 1987. Shipboard flow cytometry: Sea-trials and analysis and sorting of photosynthetic picoplankton in the Celtic Sea. XII int. SAC meeting. Cytometry, Supplement 1: 643.

Button, D.K. and B.R. Robertson. - 1989. Kinetics of bacterial processes in natural aquatic systems based on biomass as determined by high-resolution flow cytometry [erratum in Cytometry 11(3): 451, - 1990]. Cytometry 10(5): 558-563.

Button, DK. and BR. Robertson. - 1990. The status and promise of flow cytometry as a tool in aquatic bacteriology. Signal \& Noise 3 (1):3 (published by the JJ.MacIsaac Flow cytometry and cell sorting facility at Bigelow Laboratory, West Boothbay Harbor, Maine).

Button, D.K., and B. Robertson. - 2000. Effect of nutrient kinetics and cytoarchitecture on bacterioplankter size. Limnol. Oceanogr. 45(2): 499-505.

Campbell, J.W. and C.M. Yentsch. - 1989a. Variance within homogeneous phytoplankton populations, I: Theoretical framework for interpreting histograms. Cytometry 10: 587-595.

Campbell, J.W. and C.M. Yentsch. - 1989b. Variance within homogeneous phytoplankton populations, II: Analysis of clonal cultures. Cytometry 10: 596-604.

Campbell, J.W., C.M. Yentsch and T.L. Cucci. - 1989c. Variance within homogeneous phytoplankton populations, III: Analysis of natural populations. Cytometry 10: 605-611.

Campbell, L., E.J. Carpenter and V.J. Iacono. - 1983. Identification and enumeration of marine chroococcoid cyanobacteria by immunofluorescence. Appl. Env. Microbiol. 46(3): 553-559.

Campbell, L., L. P. Shapiro, E. M. Haugen, and L. Morris. - 1989. Immunochemical approaches to the identification of the ultraplankton: assets and limitations. In: E. M. Cosper, E. J. Car- 
penter and M. Bricelj (eds.), Novel Phytoplankton Blooms: Causes and Impacts of Recurrent Brown Tide and Other Unusual Blooms pp. 3956, Springer-Verlag, New York.

Campbell, L., Nolla, H.A. and D. Vaulot. - 1994. The importance of Prochlorococcus to community structure in the Central North Pacific Ocean. Limnol. Oceanogr. 39(4): 954-961.

Campbell, L., H. Liu, H.A. Nolla and D. Vaulot. - 1997. Annual variability of phytoplankton and bacteria in the subtropical North Pacific Ocean at Station ALOHA during the - 1991-1994 ENSO event. Deep-Sea Res. I, 44(2):167-192.

Campbell, L., M.R. Landry, J. Constantinou, H.A. Nolla, S.L. Brown, H. Liu and D.A. Caron. - 1998. Response of microbial community structure to environmental forcing in the Arabian Sea. DeepSea Res. II Top. Stud. Oceanogr. 45(10-11): 2301-2325.

Carr, M.R., G.A. Tarran and P.H. Burkill. - 1994. The application of multivariate statistical methods to the identification of phytoplankton from flow cytometric data: a EurOPA subproject. In OCEANS '94 OSATES: Ocean Engineering for today's technology and tomorrow's preservation. Vol. 1: 570 - 562. IEEE, New York.

Carr, M.R., G.A. Tarran and P.H. Burkill. - 1996. Discrimination of marine phytoplankton species through the statistical analysis of their flow cytometric signatures. J. Plankton Res. 18(7): 12251238 .

Cavender-Bares, K.K., E.L. Mann, S.W. Chisholm, M.E. Ondrusek and R.R. Bidigare. - 1999. Differential response of equatorial Pacific phytoplankton to iron fertilization. Limnol. Oceanogr. 44(2): $237-246$

Cavender-Bares, K.K., S.L. Frankel and S.W. Chisholm. - 1998. A dual sheath flow cytometer for shipboard analyses of phytoplankton communities from the oligotrophic oceans. Limnol. Oceanogr. 43(6): 1383-1388.

Charpy, L. and J. Blanchot. - 1999. Picophytoplankton biomass, community structure and productivity in the Great Astrolabe Lagoon, Fiji. Coral Reefs 18(3): 255-262.

Charpy, L. and J. Blanchot. - 1998. Photosynthetic picoplankton in French Polynesian atoll lagoons: estimation of taxa contribution to biomass and production by flow cytometry. Mar. Ecol. Progr. Ser. 162: 57-70.

Chekalyuk, A.M., V.V. Fadeev and M.Yu. Gorbunov. - 1992 Diagnostics of primary photosynthesis processes by laser saturation fluorometry. In: Proc. 4th Int. Conf. on Laser Applications in Life Sciences (LALS '92), Jyvaskyla, Finland.

Chekalyuk, A.M., R.J. Olson and H.M.Sosik. - 1996. Pump-duringprobe fluorometry of phytoplankton: group specific photosynthetic characteristics from individual cell analysis. In: Ackleson and Frouin (eds.) Ocean Optics XIII, SPIE Vol. 2963: 840-845.

Chisholm, S.W., E.V. Armbrust and R.J. Olson. - 1986. The individual cell in phytoplankton ecology: Cell cycles and applications of flow cytometry. In: Platt, T. and W.K.W. Li (eds.) Photosynthetic Picoplankton (Can. Bull. Fish.Aq. Sci. 214), Dept.Fish. and Oceans): 343-369.

Chisholm, S.W., R.J. Olson, E.R. Zettler, R. Goericke, J. Waterbury, and N. Welschmeyer. - 1988. A novel free-living prochlorophyte abundant in the oceanic euphotic zone. Nature 334(6180): 340-343.

Chisholm, S.W. - 1992. Phytoplankton Size. In: P.Falkowski and A.D. Woodhead (eds.), Primary Production and Biogeochemical Cycles in the Sea. Plenum Press, N.Y.

Chrétiennot-Dinet, M.J. and C. Courties. - 1997. Biodiversity of unicellular algae: example of pico- and ultraplanktonic eukaryotes of the Thau Lagoon. In: Feral, J.P. and G. Boucher (eds.), Biodiversity in dispersive environments. Congress of the French Marine Network. Paris. Vie Milieu. 47(4): 317-324.

Christaki, U., S. Jacquet, J.R. Dolan, D. Vaulot and F. Rassoulzadegan. - 1999. Growth and grazing on Prochlorococcus and Synechococcus by two marine ciliates. Limnol. Oceanogr. 44(1): 52-61.

Cid, A., P. Fidalgo, C. Herrero and J. Abalde. - 1996. Toxic action of copper on the membrane system of a marine diatom measured by flow cytometry. Cytometry 25(1): 32-36.

Cid, A., E. Torres, C. Herrero and J.E. Abalde. - 1997. Disorders provoked by copper in the marine diatom Phaedactylum tricornutum in short-time exposure assays. Cah. Biol. Mar. 38(3): 201-206.

Constantinou, J., J. Kirshtein and M.R. Landry. - 1995. Microzooplankton grazing in the central equatorial Pacific. Deep-Sea Res. II 42 (2-3): 657-671.
Corzo, A., F. Jimenez-Gomez, F. Gordillo, R. Garcia-Ruiz and F. Niell. - 1999. Synechococcus and Prochlorococcus-like populations detected by flow cytometry in a eutrophic reservoir in summer. J. Plankton Res. 21: 1575-1581.

Courties, C., A. Vaquer, M. Troussellier, J. Lautier, M. Chretiennot-Dinet, J. Neveux, C. Machado and H. Claustre. - 1994. Smallest eukaryotic organism. Nature, 370(6487): 255.

Cowles, T.J., R.J. Olson, and S.W. Chisholm. - 1988. Food selection by copepods: Discrimination on the basis of food quality. Mar. Biol. 100: 41-49.

Cucci, T.L., S.E. Shumway, R.C. Newell, R. Selvin, R.R.L. Guillard and C.M. Yentsch. - 1985. Flow cytometry: a new method for characterization of differential ingestion, digestion and egestion by suspension feeders. Mar. Ecol. Prog. Ser. 24: 201204.

Cucci, T.L., S.E. Shumway, W.S. Brown, and C.R. Newell. - 1989. Using phytoplankton and flow cytometry to analyse grazing by marine organisms. Cytometry 10: 659-669.

Cullen, J.J., C.M. Yentsch, T.L. Cucci, and H.L. MacIntyre. - 1988. Autofluorescence and other optical properties as tools in biological oceanography. SPIE (Ocean Optics IX) 925: 149-156.

Cunningham, A. - 1990a. A low-cost portable flow cytometer specifically designed for phytoplankton analysis. J. Plankton Res. 12 (1): 149-160.

Cunningham, A. - 1990b. Fluorescence pulse shape as a morphological indicator in the analysis of colonial microalgae by flow cytometry. J. Microb. Meth. 11: 27-36.

Cunningham, A. and G.A. Buonaccorsi. - 1992. Narrow-angle forward light scattering from individual algal cells: implications for size and shape discrimination in flow cytometry. J. Plankton Res. 14: 223-234.

Del Giorgio, P.A., D.F. Bird, Y.T. Prairie and D. Planas. - 1996. The flow cytometric determination of bacterial abundance in lake plankton using the nucleic acid stain SYTO 13. Limnol. Oceanogr. 41: 783-789.

Del Giorgio, P.A., Y.T. Prairie and D.F. Bird. - 1997. Coupling Between Rates of Bacterial Production and the Abundance of Metabolically Active Bacteria in Lakes, Enumerated Using CTC Reduction and Flow Cytometry. Microb. Ecol. 34: 144154.

Demers, S., K. Davis, and T.L. Cucci. - 1989. A flow cytometric approach to assessing the environmental and physiological status of phytoplankton. Cytometry 10: 644-652

Demers, S. (Ed.). - 1991. Particle analysis in oceanography. NATO ASI Series, G: Ecological Sciences, Vol. 27, SpringerVerlag Berlin Heidelberg.

Demers, S., J. Kim, P. Legendre and L. Legendre. - 1992. Analyzing multivariate flow cytometric data in aquatic sciences. Cytometry 13(3): 291-299.

Detmer, A.E. and U. V. Bathmann. - 1997. Distribution patterns of autotrophic pico- and nanoplankton and their relative contribution to algal biomass during spring in the Atlantic sector of the Southern Ocean Deep-Sea Res. II 44(1-2): 299-320.

Dorsey, J., C.M. Yentsch, S. Mayo, and T.L. Cucci. - 1989. Rapid analytical technique for the assessment of cell metabolic activity in marine microalgae. Cytometry 10: 622-628.

Dubelaar, G.B.J., J.W.M. Visser and M. Donze. - 1987. Anomalous behaviour of forward and perpendicular light scattering of a cyanobacterium owing to intracellular gasvacuoles. Cytometry 8: 405-412.

Dubelaar, G.B.J., A.C. Groenewegen, W. Stokdijk, G.J. van den Engh and J.W.M. Visser. - 1989. The optical plankton analyser (OPA): a flow cytometer for plankton analysis, II: Specifications. Cytometry, 10: 529-539.

Dubelaar, G.B.J., R.R. Jonker, J.T.M. Meulemans and J.J.F. van Veen. - 1994. Phytoplankton analysis by (EurOPA) flow cytometry, current and future applications in environmental control. In: Proceedings Oceans 94 OSATES, Vol. 1: 683-689, IEEE, Piscataway, NJ-USA

Dubelaar, G.B.J. and C.S. van der Reijden. - 1995a. Size distributions of Microcystis aeruginosa colonies: a flow cytometric approach. Water Science and Technology, 32(4): 171-176.

Dubelaar, G.B.J., A. Cunningham, A.C. Groenewegen, J. Klijnstra, L. Boddy, M.F. Wilkins, R.R. Jonker and J. Ringelberg. 1995b. A European optical plankton analysis system: flow cytometer based technology for automated phytoplankton identification and quantification. In: Weydert M, Lipiatou E, Goñi $\mathrm{R}$, Fragakis C, Bohle-Carbonell M, Barthel KG (eds.): Marine 
Science and Technology, Second MAST days and EUROMAR Market. Project reports. Vol. 2: 946-956. Commission of the European Community, Luxembourg

Dubelaar, G.B.J., P.L. Gerritzen, A.E.R. Beeker, R.R. Jonker and K. Tangen. -1999. Design and first results of the CYTOBUOY: an autonomous flow cytometer with wireless datatransfer for in situ analysis of marine and fresh waters. Cytometry 37: 247254.

Dubelaar, G.B.J. and P.L. Gerritzen. - 2000. CytoBuoy: a step forward towards using flow cytometry in Operational Oceanography. Sci. Mar., 64(2): 255-265.

DuRand, M.D., R.J. Olson and E. R. Zettler. - 1994. Flow cytometric analysis of phytoplankton growth during diel studies in the Equatorial Pacific. E.O.S., Transactions, American Geophysical Union, 75: 28-29.

DuRand, M.D. and R.J. Olson. - 1996. Contributions of phytoplankton light scattering and cell concentration changes to diel variations in beam attenuation in the equatorial Pacific from flow cytometric measurements of pico-, ultra-, and nanoplankton. Deep-Sea Res. 43: 891-906.

Dusenberry, JA, and S.L. Frankel. - 1994. Increasing the sensitivity of a FACScan flow cytometer to study oceanic picoplankton. Limnol. Oceanogr. 39(1): 206-209.

Duysens, L.N.M. - 1956. The flattening of the absorption spectrum of suspensions, as compared to that of solutions. Biochim. Biophys. Acta. 19: 1-12.

Edvardsen, B. and D. Vaulot. - 1996. Ploidy analysis of the two motile forms of Chrysochromulina polylepis (Prymnesiophyceae). J. Phycol. 32: 94-102.

Eisert, W.G. - 1979. Cell differentiation based on absorption and scattering. J. Histochemistry and Cytochemistry 27 (1): 404409.

Endo, H., J. Nakayama, T. Hayashi and E. Watanabe. - 1997. Application of flow cytometry for rapid determination of cell number of viable bacteria. Fish. Sci. 63 (6): 1024-1029.

Engh, G.J. van den, and C. Farmer. - 1992. Photo-bleaching and photon saturation in flow cytometry. Cytometry 13: 669-677.

Faber, M.J., D.G. Thompson, G.R. Stephenson and H.J. Boermans. - 1998. Impact of glufosinate-ammonium and bialaphos on the phytoplankton community of a small eutrophic northern lake. Environ. Toxicol. Chem. 17(7): 1282-1290.

Firth, J.R., J.P. Diaper and C. Edwards. - 1994. Survival and viability of Vibrio vulnificus in seawater monitored by flow cytometry. Lett. Appl. Microbiol. 18(5): 268-271.

Forrest, J.I.M. - 1985. Classification of microalgal cells in flow cytometry: the potential of multiple angle light scatter measurements. Ph.D. Thesis, University of Strathclyde, Glasgow.

Frankel, D.S., R.J. Olson, S.L. Frankel, and S.W. Chisholm. - 1989. Use of a neural net computer system for analysis of flow cytometric data of phytoplankton populations. Cytometry 10(5): 540-550.

Frankel, D.S., S.L. Frankel, B.J. Binder and R.F. Vogt. - 1996. Application of neural networks to flow cytometry data analysis and real-time cell classification, Cytometry 23(4): 290-302.

Frankel, S.L., B.J. Binder, H.M. Shapiro and S.W. Chisholm. 1990. A high-sensitivity flow cytometer for studying picoplankton. Limnol. Oceanogr. 35(5): 1164-1169.

Franqueira, D., A. Cid, E. Torres, M.Orosa and C. Herrero. - 1999. A comparison of the relative sensitivity of structural and functional cellular responses in the alga Chlamydomonas eugametos exposed to the herbicide paraquat. Arch. Envir. Cont. Toxicol. 36(3): 264-269.

Fuhrman, J.A. - 1999. Marine viruses and their biogeochemical and ecological effects. Nature (London) 399: 541-548.

Furuya, K. and W.K.W. Li. - 1992. Evaluation of photosynthetic capacity in phytoplankton by flow cytometric analysis of DCMU-enhanced chlorophyll fluorescence. Mar. Ecol. Progr. Ser. 88: 279-287.

Gala, W.R. and J.P. Giesy. - 1990. Flow cytometric techniques to assess toxicity to algae. In: 13th Symposium aquatic tox. and risk ass. (1989). Am. Soc. Test. Mat. - Sp. Techn. Publ. 1096: 237-246.

Gala, W.R. and J.P. Giesy. - 1994. Flow cytometric determination of the photoinduced toxicity of anthracene to the green alga Selenastrum capricornutum. Environ. Tox. Chem. 13 (5): 831840.

Gasol, J.M., and X.A. G. Morán. - 1999. Effects of filtration on bacterial activity and picoplankton community structure as assessed by flow cytometry. Aquatic Microbial Ecology 16: 251-264.

Gasol, J.M., P.A. del Giorgio and C.M. Duarte. - 1997. Biomass distribution in marine planktonic communities. Limnol. Oceanogr. 42(6): 1353-1363.

Gasol, J.M. and P.A. del Giorgio. - 2000. Using flow cytometry for counting natural planktonic bacteria and understanding the structure of planktonic bacterial communities. Sci.Mar., 64(2): 197-224.

Garrison, D.L., M.M. Gowing, M.P. Hughes, L. Campbell, D.A Caron, M.R. Dennett, A. Shalapyonok, R.J. Olson, M.R. Landry, S.L. Brown, H. Liu, F. Azam, G.F. Steward, H.W. Ducklow and D.C. Smith. - 2000. Microbial food web structure in the Arabian Sea: a US JGOFS study. Deep Sea Res. Part II: Topical Studies In Oceanography 47(7-8): 1387-1422.

Geider, R., P. Burkill, L. Boddy, R.R. Jonker, C. Morris, B. Osborne, J. Rodriguez and L. Medlin. - 1998. Automated Identification and characterisation of microbial populations (project AIMS). In: K.G. Barthel, H. Barth, M. Bohle-Carbonell, C. Fragakis, E. Lipiatou, P. Martin, G. Ollier and M. Weydert (eds.), European marine science and technology: Project synopses Vol. 3: 1027-1036, Commission of the European Community, Luxembourg.

Gerath M.W. and S.W. Chisholm. - 1989. Change in photosynthetic capacity over the cell cycle in light-dark-synchronized Amphidinium-carteri is due solely to the photocycle. Plant Physiol. (Bethesda) 91(3): 999-1005.

Gerritsen J. and R.W. Sanders. - 1987. Individual feeding variability of protozoan and crustacean zooplankton analysed with flow cytometry. Limnol. Oceanogr. 32(3): 691-699.

Gin, K.Y.H., S.W. Chisholm and R.J. Olson. - 1999. Seasonal and depth variation in microbial size spectra at the Bermuda Atlantic time series station. Deep-Sea Res. Part I : Oceanogr Res. Papers 46(7): 1221-1245.

Gisselson, L-Å., E. Granéli and P. Carlsson. - 1999. Using cell cycle analysis to estimate in situ growth rate of the dinoflagellate Dinophysis acuminata: drawbacks of the DNA quantification method. Mar. Ecol. Progr. Ser. 184: 55-62.

González-Gil, S., B.A. Keafer, R.V.M. Jovine, A. Aguilera, S. Lu and D.M. Anderson. - 1998. Detection and quantification of alkaline phosphatase in single cells of phosphorus-starved marine phytoplankton. Mar. Ecol. Progr. Ser. 164: 21-35.

Graziano, L.M., R.J. Geider, W.K.W. Li and M. Olaizola. - 1996. Nitrogen limitation of North Atlantic phytoplankton: analysis of physiological condition in nutrient enrichment experiments Aquat. Microb. Ecol. 11: 53-64.

Green, J.C., P.A. Course and G.A. Tarran. - 1996. The life-cycle of Emiliania huxleyi: A brief review and a study of relative ploidy levels analysed by flow cytometry. J. Mar. Syst. 9(1-2): 33-44.

Guindulain, T., J. Comas and J. Vives-Rego. - 1997. Use of nucleic acid dyes SYTO-13, TOTO-1, and YOYO-1 in the study of Escherichia and marine prokaryotic populations by flow cytometry. Appl. Environ. Microbiol. 63(11): 4608-4611,

Hansen, F.C., H.J. Witte and J. Passarge. - 1996. Grazing in the heterotrophic dinoglagellate Oxyrrhis marina: size selectivity and preference for calcified Emiliania huxleyi. Aquat. Microb. Ecol. 10: $307-313$

Haugen, E.M., T.L. Cucci, C.M. Yentsch and L.P. Shapiro. - 1987. Effects of flow cytometric analysis on morphology and viability of fragile phytoplankton. Appl. Environ. Microbiol. 53(11): 2677-2679.

Hess, W.R., F. Partensky, G.W.M. van der Staay, J. Garcia-Fernandez, T. Boerner and D. Vaulot. - 1996. Coexistence of phycoerythrin and a chlorophyll a/b in a marine prokaryote. Proc Nat. Acad. Sci. USA 93: 11126-11130.

Hilton, J., E. Rigg and G. Jaworski. - 1989. In vivo algal fluorescence, spectral change due to light intensity changes and the automatic characterization of algae. Fresh. Biol. 21: 375-382.

Hofstraat, J.W, W.J.M. van Zeijl, J.C.H. Peeters, L. Peperzak and G.B.J. Dubelaar. - 1990. Flow cytometry and other optical methods for characterization and quantification of phytoplankton in seawater. Environment and pollution measurement sensors and systems, SPIE Vol. 1269: 116-132.

Hofstraat, J.W., M.E.J. de Vreeze, W.J.M. van Zeijl, L. Peperzak, J.C.H. Peeters and H.W. Balfoort. - 1991. Flow cytometric discrimination of phytoplankton classes by fluorescence and excitation properties, J. Fluoresc. 1 (4): 249-265.

Hofstraat, J.W., W.J.M. van Zeijl, M.E.J. de Vreeze, J.C.H. Peeters, 
L. Peperzak, F. Colijn and T.W.M. Rademaker. - 1994. Phytoplankton monitoring by flow cytometry, J. Plankton Res. 19(9): 1197-1224

Holligan, P.M. and W.M. Balch. - 1991. From the ocean to cells: coccolithophore optics and biochemistry. In: S. Demers (ed.), Particle analysis in oceanography NATO ASI Series, G: Ecological Sciences, Vol. 27, Springer-Verlag Berlin Heidelberg.

Huisman, J., R.R. Jonker, C. Zonneveld, and F.J. Weissing. - 1999. Competition for light between phytoplankton species: experimental tests of mechanistic theory. Ecology, 80(1): 211-222.

Hull, H.M., R.W. Hoshaw and J.C. Wang. - 1982. Cytofluorometric determination of nuclear DNA in living and preserved algae. Stain Technology 57 (5): 273-282.

Hüller, R., S. Schmidlechner, E. Gloßner, S. Schaub and V. Kachel. - 1991. A macro flow planktometer for analysis of large marine plankton organisms. Cytometry Supplement 5: 53.

Jacquet, S., J.-F. Lennon, D. Marie, and D. Vaulot. - 1998. Picoplankton population dynamics in coastal waters of the northwestern Mediterranean Sea. Limnol. Oceanogr., 43(8): 1916-1931.

Jellett, J.F., W.K.W. Li, P.M. Dickie, A. Boraie and P.E. Kepkay. 1996. Metabolic activity of bacterioplankton communities assessed by flow cytometry and single carbon substrate utilization. Mar. Ecol. Prog. Ser. 136: 213-225.

Jochem, F.J., and D. Meyerdierks. - 1999. Cytometric measurement of the DNA cell cycle in the presence of chlorophyll autofluorescence in marine eukaryotic phytoplankton by the blue-light excited dye YOYO-1. Mar. Ecol. Progr. Ser. 185: 301-307.

Jochem, F.J. - 2000. Probing the physiological state of phytoplankton at the single-cell level. Sci. Mar., 64(2): 183-195.

Johnson, Z., M.L. Landry, R.R. Bidigare, S.L. Brown, L. Campbell, J. Gunderson, J. Marra and C. Trees. - 1999. Energetics and growth kinetics of a deep Prochlorococcus spp. population in the Arabian Sea. Deep Sea Res. Part II: Topical Studies In Oceanography 46(8-9): 1719-1743.

Jonker R.R., J.T.M. Meulemans, G.B.J. Dubelaar, M.F. Wilkins and J. Ringelberg. - 1995. Flow cytometry: a powerful tool in analysis of biomass distributions in phytoplankton. Water Science and Technology 32 (4): 177-182.

Jonker R.R., R. Groben, G. Tarran, L. Medlin, M. Wilkins, L. Garcia, L. Zabala and L. Boddy - 2000. Automated identification and characterization of microbial populations using flow cytometry: The AIMS Project. Sci. Mar, 64(2): 225-234.

Joux, F., P. Lebaron and M. Troussellier. - 1997. Changes in cellular states of the marine bacterium Deleya aquamarina under starvation conditions. Appl. Environ. Microbiol., 63(7): 2686-2694.

Kachel, V. and J. Wietzorrek. - 2000. Flow cytometry and integrated imaging. Sci. Mar., 64(2): 247-254.

Kenter, U., U. Zimmermann and H. Muller. - 1996. Grazing rates of the feshwater ciliate Balanion planctonicum determined by flow cytometry. J. Plankton Res., 18: 1047-1053.

Kerker, M., M.A. van Dilla, A. Brunsting, J.P. Kratohvil, P. Hsu, D.S. Wang, J.W. Gray and R.G. Langlois. - 1982. Is the central dogma of flow cytometry true: that fluorescence intensity is proportional to cellular dye content? Cytometry 3: 71-78.

Koch, A.L. - 1986. Estimation of size of bacteria by low-angle light scattering measurements: theory. J. Microbiol. Meth. 5: 221-235.

Koch, A.L., B.R. Robertson and D.K. Buton. - 1996. Deduction of the cell volume and mass from forward scatter intensity of bacteria analysed by flow cytometry. J. Microbiol. Meth. 27: 49-61.

Knauber, D.C., E.S. Berry and M.W. Fawley. - 1996. Ribosomal RNA-based oligonucleotide probes to identify marine green ultraphytoplankton. J. Euk. Microbiol. 43(2): 89-94.

Kuipers, B. R., and H. J. Witte. - 1999. Grazing impact of microzooplankton on different size classes of algae in the North Sea in early spring and mid-summer. Mar. Ecol. Progr. Ser. 180: 93-104.

Landry, M.R., J. Kirshtein and J. Constantinou. - 1996. Abundances and distributions of picoplankton populations in the central equatorial Pacific from $12^{\circ} \mathrm{N}$ to $12^{\circ} \mathrm{S}, 140^{\circ} \mathrm{W}$. Deep-Sea Res. 43(4-6): 871-890.

Lange M., L. Guillou, D. Vaulot, N. Simon, R. Amann, W. Ludwig and L.K. Medlin. - 1996. Identification of the class Prymnesiophyceae and the genus Phaeocystis with ribosomal RNA-targeted nucleic acid probes detected by flow cytometry. J. Phycol. 32: 858-868.

Lebaron, P., N. Parthuisot and P. Catala. - 1998a. Comparison of blue nucleic acid dyes for flow cytometric enumeration of bac- teria in aquatic systems. Appl. Environ. Microbiol. 64(5): 17251730.

Lebaron, P., P. Catala, and N. Parthuisot. - 1998b. Effectiveness of SYTOX Green stain for bacterial viability assessment. Appl. Environ. Microbiol., 64(7): 2697-2700.

Lebaron, P., P. Servais, M. Troussellier, C. Courties, J. Vives-Rego, G. Muyzer, L. Bernard, T. Guindulain, H. Schäfer, E. Stackebrandt. - 1999. Changes in bacterial community structure in seawater mesocosms differing in their nutrient status. Aquat. Microb. Ecol. 19: 255-267.

Lee, J.J., Y. Chan, and A. Lagziel. - 1988. In: Immunochemical approaches to coastal estuaries and oceanographic questions. pp.230-241. Springer Verlag, Berlin.

Lefort, T.M., M.H. Bre, M. Pouphile and P. Manigault. - 1987. DNA flow cytometry of control Euglena and cell cycle blockade of vitamin B12-starved cells. Cytometry 8(1): 46-54.

Legendre, L., and J. Le Fevre. - 1991. From individual plankton cells to pelagic marine ecosystems and to global biochemical cycles. In: S. Demers (ed.), Particle analysis in oceanography. NATO ASI Series, G: Ecological Sciences, Vol. 27, SpringerVerlag Berlin Heidelberg.

Legner, M. - 1990. Phytoplankton quantity assessment by means of flow cytometry. Mar. Microb. Food Webs 4(2): 161-174.

Lepesteur, M., J.M. Martin and A. Fleury. - 1993. Acomparative study of different preservation methods for phytoplankton cell analysis by flow cytometry. Mar. Ecol. Progr. Ser. 93: 55-63.

Lesser, P.M., S.E. Shumway, T.L. Cucci, J. Barter, and J. Edwards. 1991. Size specific selection of phytoplankton by juvenile filterfeeding bivalves: comparison of the sea scallop Placopectin magellanicus (Gmelin, 1791) with Mya arenaria Linneaus, 1758 and Mytilus edulis Linneaus, 1758. In: S.E. Shumway and P.A. Sandifer (eds.), Scallop Biology and Culture, The World Aquaculture Society, the 7th International Pectinid Workshop: 341-346.

Lewis, M.R. and J.J. Cullen. - 1991. From cells to the ocean: sattelite ocean color. In: S. Demers (ed.), Particle analysis in oceanography, NATO ASI Series, G: Ecological Sciences, Vol. 27, Springer-Verlag Berlin Heidelberg.

Li, W.K.W., and A.M. Wood. - 1988. Vertical distribution of northern atlantic ultraphytoplankton analysis by flow cytometry and epifluorescence microscopy. Deep-Sea Res. Part A Oceanogr. Res. Pap. 35(9): 1615-1638

Li, W.K.W. - 1989. Shipboard analytical flow cytometry of oceanic ultraphytoplankton. Cytometry 10 (5): 564-580.

Li, W.K.W. - 1990. Bivariate and trivariate analysis in flow cytometry: Phytoplankton size and fluorescence. Limnol. Oceanogr. 35: 1356-1367.

Li, WKW. - 1994. Primary production of prochlorophytes, cyanobacteria, and eucaryotic ultraphytoplankton: Measurements from flow cytometric sorting. Limnol. Oceanogr., 39(1): $169-175$

Li, W.K.W. - 1995. Composition of ultraphytoplankton in the central North Atlantic. Mar. Ecol. Progr. Ser. 122: 1-8.

Li, W.K.W., J.F. Jellett and P.M. Dickie. - 1995. DNA distributions in planktonic bacteria stained with TOTO or TO-PRO. Limnol. Oceanogr. 40(8): 1485-1495.

Li, W.K.W. - 1997. Cytometric diversity in marine ultraphytoplankton. Limnol. Oceanogr. 42(5): 874-880.

Lim, E.L., L.A. Amaral, D.A. Caron and E.F. DeLong. - 1993. Application of rRNA-based probes for observing marine nanoplanktonic protists. Appl. Environ. Microbiol. 59(5): 16471655.

Lipschultz, F. - 1995. Nitrogen-specific uptake rates of marine phytoplankton isolated from natural populations of particles by flow cytometry. Mar. Ecol. Progr. Ser. 123: 245-258.

Liu, H., H.A. Nolla and L. Campbell. - 1997. Prochlorococcus growth rate and contribution to primary production in the equatorial and subtropical North Pacific Ocean. Aquat. Microb. Ecol. 12: 39-47.

Marie D., D. vaulot and F. Partensky. - 1996. Application of the novel DNA dyes YOYO-1, YOPRO-1 and Picogreen for flow cytometric analysis of marine prokaryotes. Appl. Environ. Microbiol. 62: 1649-1655.

Marie D., F. Partensky, S. Jacquet and D. Vaulot. - 1997. Enumeration and cell cycle analysis of natural populations of marine picoplankton by flow cytometry using the nucleic acid stain SYBR Green I. Appl. Environ. Microbiol. 63: 186-193.

Marie, D.,C.P.D. Brussaard, R. Thyrhaug, G. Bratbak and D. Vaulot. - 1999. Enumeration of marine viruses in culture and 
natural samples by flow cytometry. Appl. Environ. Microbiol. 65 (1): 45-52.

Marie, D., F. Partensky, D. Vaulot, and C. Brussaard. - 1999. Enumeration of Phytoplankton, Bacteria, and Viruses in Marine Samples. In: J.P. Robinson, Z. Darzynkiewicz, P.N. Dean, A. Orfao, P.S. Rabinovitch, C.C. Stewart, H.J. Tanke, L.L. Wheeless (eds.) Current Protocols in Cytometry 11.11.1-15, John Wiley \& Sons. Inc., New York.

Marie D., N. Simon, L. Guillou, F. Partensky and D. Vaulot. - 2000. DNA/RNA Analysis of Phytoplankton by Flow Cytometry In: J.P. Robinson, Z. Darzynkiewicz, P.N. Dean, A. Orfao, P.S. Rabinovitch, C.C. Stewart, H.J. Tanke, L.L. Wheeless (eds.) Current Protocols in Cytometry. 11.12.1-14. John Wiley \& Sons, Inc., New York.

Monger, B.C., M.R. Landry and S.L. Brown, - 1999. Feeding selection of heterotrophic marine nanoflagellates based on the surface hydrophobicity of their picoplankton prey. Limnol. Oceanogr. 44(8): 1917-1927.

Moreira-Turcq, P.F., and J.M. Martin. - 1998. Characterisation of fine particles by flow cytometry in estuarine and coastal Arctic waters. J. Sea Res. 39(3-4): 217-226.

Morel, A., and L. Prieur. - 1977. Analysis of variations in ocean color. Limnol. Oceanogr. 22: 709-722.

Morel, A. - 1991. Optics of marine particles and marine optics. In: S. Demers (ed.), Particle analysis in oceanography. NATO ASI Series, G: Ecological Sciences, Vol. 27, Springer-Verlag, Berlin.

Mostajir, B., T.S. Ngando, S. Demers, C. Belzile, S. Roy, M. Gosselin, J-P. Chanut, S. de Mora, J. Fauchot, F. Vidussi and M. Levasseur. - 1999. Ecological implications of changes in cell size and photosynthetic capacity of marine Prymnesiophyceae induced by ultraviolet-B radiation. Mar. Ecol. Progr. Ser. 187: 89-100.

Navaluna, N.A., M.J. Perry and M.C. Talbot. - 1989. The effect of chemical fixation on some optical properties of phytoplankton. J. Plankton Res. 11(1): 15-24.

Neale, P.J., J.J. Cullen, and C.M. Yentsch. - 1989. Bio-optical inferences from chlorophyll a fluorescence: What kind of fluorescence is measured in flow cytometry? Limnol. Oceanogr. 34: 1739-1748.

Olson, R.J., S.L. Frankel, S.W. Chisholm and H.M. Shapiro. 1983. An inexpensive flow cytometer for the analysis of fluorescence signals in phytoplankton: Chlorophyll and DNA distributions. J. Exp. Mar. Biol. Ecol., 68: 129-144.

Olson, R.J., D. Vaulot and S.W. Chisholm. - 1985. Marine phytoplankton distributions measured using shipboard flow cytometry. Deep-Sea Res. 10: 1273-1280.

Olson, R.J., D. Vaulot and S.W. Chisholm. - 1986. Effects of environmental stresses on the cell cycle of two marine phytoplankton species. Plant Physiol., 80: 918-925.

Olson, R.J. and S.W. Chisholm. - 1986. Effects of light and nitrogen limitation on the cell cycle of the dinoflagellate Amphidinium carteri. J. Plank. Res. 8(4): 785-793.

Olson, RJ., E.R. Zettler and O.K. Anderson. - 1989. Discrimination of eukaryotic phytoplankton cell types from light scatter and autofluorescence properties measured by flow cytometry. Cytometry 10(5): 636-644.

Olson, R.J., S.W. Chisholm, E.R. Zettler, and E.V. Armbrust. 1990. Pigments, size, and distribution of Synechococcus in the North Atlantic and Pacific Oceans. Limnol. Oceanogr. 35(1): 45-58.

Olson, R.J., E.R. Zettler, S.W. Chisholm and J.A. Dusenberry. 1991. Advances In Oceanography Through Flow Cytometry. In: S. Demers (ed.) Particle Analysis in Oceanography, NATO ASI Series, G: Ecological Sciences, Vol. 27, Springer-Verlag, Heidelberg Berlin, 351-399.

Olson, R.J. and E.R. Zettler. - 1995. Potential of flow cytometry for "pump and probe" fluorescence measurements of phytoplankton photosynthetic characteristics, Limnol. Oceanogr. 40(4): 816-820.

Olson, R.J., A.M. Chekalyuk H.M. Sosik. - 1996. Phytoplankton photosynthetic characterisation from fluorescence induction assays of individual cells. Limnol. Oceanogr. 41: 1253-1263.

Olson, R.J. and H.M. Sosik. - 1999. An in situ flow cytometer for the optical analysis of individual particles in seawater. Internet page, based on a poster presented at the 1999 ASLO Meeting in Santa Fe: http://www.whoi.edu/science/B/Olsonlab/aslo.htm

Owens, T.G. - 1991. Energy transformation and fluorescence in photosynthesis. In: S. Demers (ed.) Particle Analysis in Oceanography, NATO ASI Series, G: Ecological Sciences, Vol. 27, Springer-Verlag, Heidelberg-Berlin.

Paau, A.S., J. Oro and J.R. Cowles. - 1978. Application of microfluorometry to the study of algal cells and isolated chloroplasts. J. Exp. Bot. 29: 1011-1020.

Paau, A.S., J.A. Cowles J. Oro, A. Bartel and E. Hungerford. 1979. Separation of algal mixtures and bacterial mixtures with flow-microfluorometer using chlorophyll and ethidium bromide fluorescence. Arch. Microbiol. 120: 271-273.

Pan, Y. and A.D. Cembella. - 1996. Comparison of the three GreenFluorescing DNA stains in flow cytometric studies of growth rates and cell cycles of dinoflagellates and diatoms. Can. Tech. Rep. Fish. Aquat. Sci. 2138: 150-152.

Pan, Y., A. D. Cembella and M. A. Quilliam. - 1999. Cell cycle and toxin production in the benthic dinoflagellate Prorocentrum lima. Mar. Biol. 134(3): 541-549.

Parpais, J., D. Marie, F. Partensky, P. Morin and D. Vaulot. - 1996. Effect of phosphorus starvation on the cell cycle of the photosynthetic prokaryote Prochlorococcus. Mar. Ecol. Progr. Ser. 132: 265-274.

Partensky, F., J. Blanchot, F. Lantoine, J. Neveux and D. Marie. 1996. Vertical structure of picophytoplankton at different trophic sites of the subtropical northeastern Atlantic ocean. Deep-Sea Res. I 43(8): 1191-1213.

Partensky, F., Guillou, L., Simon, N., Vaulot, D. - 1997. Recent advances in the use of molecular techniques to assess the genetic diversity of marine photosynthetic microorganisms. In: Feral, J.P. and G. Boucher (eds.), Biodiversity in dispersive environments. Congress of the French Marine Network. Vie Milieu. 47(4): 367-374.

Peeters, J.C.H., G.B.J. Dubelaar, J. Ringelberg and J.W.M. Visser. - 1989. The optical plankton analyser (OPA): a flow cytometer for plankton analysis, I: Design considerations. Cytometry 10: 522-528.

Peperzak, L., B. Sandee, R.R. Jonker, C. Legrand. - 1998. Measurement of Prorocentrum micans growth rate by flow cytometric analysis of the dial DNA cycle. In: B. Reguera, J. Blanco, M.L. Fernandez and T. Wyatt (eds.), Harmful Algae, Proc. VIII Int. Conf. on Harmful Algae. 1997, Vigo, Spain.

Peperzak, L., E.G. Vrieling, B. Sandee and T. Rutten. - 2000. Immuno flow cytometry in marine phytoplankton research. Mar. Sci., 64(2): 165-181.

Perry, M.J., and S.M. Porter. - 1989. Determination of the crosssection absorption coefficient of individual phytoplankton cells by analytical flow cytometry. Limnol. Oceanogr. 34: 17271738.

Pichard, S.L.,L.Campbell, K. Carder, J.B. Kang, J. Patch, F.R. Tabita and J.H. Paul. - 1997. Analysis of ribulose bisphosphate carboxylase gene expression in natural phytoplankton communities by group-specific gene probing. Mar. Ecol. Progr. Ser. 149(1-3): 239-253.

Pile, A.J., M.R. Patterson, M. Savarese, V.I. Chernykh and V.A. Fialkov. - 1997. Trophic effects of sponge feeding within Lake Baikal's littoral zone. 2. Sponge abundance, diet, feeding efficiency, and carbon flux. Limnol. Oceanogr. 42(1): 178-184.

Pomponi, S.A. and T.L. Cucci. - 1989. Separation and concentration of phytoplankton populations using centrifugal elutriation. Cytometry 10: 580-586.

Porter, J., D. Deere, M. Hardman, C. Edwards and R. Pickup. 1997. Go with the flow - use of flow cytometry in environmental microbiology. FEMS. Microbiol. Ecol. 24(2): 93-101.

Premazzi, G., G. Buonaccorsi and P. Zilio. - 1989. Flow cytometry for algal studies. Water Research 23: 431-442.

Premazzi, G., F. Bertona, S. Binda, G. Bowe and E. Rodari. - 1992. Application of innovative methods for phytoplankton analysis. EUR 14806, European Communities - JRC.

Rao, D.V.S., F. Partensky, G. Wohlgeschaffen and W.K.W. Li. 1991. Flow cytometry and microscopy of gametogenesis in Nitzschia pungens, a toxic, bloom-forming, marine diatom. $J$. Phycol. 27: 21-26.

Reckermann, M. and M.J.W. Veldhuis. - 1997. Trophic interactions between picophytoplankton and micro- and nanozooplankton in the western Arabian Sea during the NE monsoon - 1993. Aquat. Microb. Ecol. 12(3): 263 - 273.

Reckermann, M. - 2000. Flow Sorting in Aquatic Ecology. Sci. Mar., 64(2): 235-246.

Reed, D.C., M. A. Brzezinski, D.A. Coury, W.M. Graham and R.L. 
Petty. - 1999. Neutral lipids in macroalgal spores and their role in swimming. Mar. Biol. 133(4): 737-744.

Rice, J., M.A. Sleigh, P.H. Burkill, G.A. Tarran, C.D. O'Connor and M. Zubkov. - 1997. Flow cytometric analysis of characteristics of hybridization of species-specific fluorescent oligonucleotide probes to rRNA of marine nanoflagellates. Appl. Environ. Microbiol. 63: 938-944

Rivkin, R.B., D.A. Phinney and C.M. Yentsch. - 1986. Effects of flow cytometric analysis and cell sorting on photosynthetic carbon uptake by phytoplankton in cultures and from natural populations. Appl. Environ. Microbiol. 52(4): 935-938.

Robertson, B.R. and D.K. Button. - 1989. Characterizing aquatic bacteria according to population, cell size and apparent DNA content by flow cytometry. Cytometry 10(1): 70-76.

Robertson, B.R., D.K. Button and A.L.Kloch. - 1998. Determination of the biomasses of smallbacteria at low concentrations in a mixture of species with forward light scatter measurements by flow cytometry. Appl. Environ. Microbiol. 64: 3900-3909.

Rodriguez, J. and W.K.W. Li. - 1994. The size structure and metabolism of the pelagic ecosystem. Sci. Mar. 57(1-2): 1-167.

Schäfer, H., B. Bruckmeyer, C. Steinberg and W. Beisker. - 1996. Three-laser flow cytometry for simultaneous measurement of photosynthesis pigments and protein content of phytoplankton populations in lakes and rivers. Proceedings of the DGZ Heidelberg Meetings, DKFZ, Heidelberg.

Sellner, K.G., S.E. Shumway, M.W. Luckenbach and T.L. Cucci. 1994. The effects of dinoflagellate blooms on the oyster Cras sostrea virginica in Chesapeake Bay. In: Lassus P. (ed.), Proceedings of the 6th International Conference on Toxic Marine Phytoplankton, Nantes.

Shalapyonok, A., R.J. Olson and L.S. Shalapyonok. - 1998. Ultradian growth in Prochlorococcus spp. Appl. Env. Microbiol. 64(3): 1066-1069.

Shapiro, L.P., L. Campbell and E.M. Haugen. - 1989. Immunochemical recognition of phytoplankton species. Mar. Ecol. Prog. Ser. 57: 219-224.

Shimada, A., T. Hasegawa, I. Umeda, N. Kadoya and T. Maruyama. - 1993. Spatial mesoscale patterns of West Pacific picophytoplankton as analysed by flow cytometry: their contribution to subsurface chlorophyll maxima. Mar. Biol., 115: 209-215.

Shimada, A., M. Nishijima and T. Maruyama. - 1995. Seasonal appearance of Prochlorococcus in Suruga Bay, Japan in - 19921993. J. Oceanogr. 51: 291-302.

Sieracki, M.E., E.M. Haugen and T.L. Cucci. - 1995. Overestimation of heterotrophic bacteria in the Sargasso Sea: direct evidence by flow and imaging cytometry. Deep Sea Res. Part I Oceanogr. Res. 42(8): 1399-1409.

Simon, N., R.G. Barlow, D. Marie, F. Partensky and D. Vaulot. 1994. Flow cytometric analysis of oceanic photosynthetic picoeucaryotes. J. Phycol. 30: 922-935.

Simon, N., N. Le Bot, D. Marie, F. Partensky and D. Vaulot. 1995. Fluorescent in situ hybridization with rRNA-targeted probes for identifying small phytoplankton by flow cytometry. Appl. Environ. Microbiol. 61: 2506-2513.

Simon, N., Brenner, J., Edvardsen, B. and Medlin, L.K. - 1997. The identification of Chrysochromulina and Prymnesium species (Haptophyta, Prymnesiophyceae) using fluorescent or chemiluminescent oligonucleotide probes: a means for improving studies on toxic algae. Europ. J. Phycol. 32(4): 393-401.

Smits, J.R.M., L.W. Breedveld, M.W.J. Derksen, G. Kateman, H.W. Balfoort, J. Snoek and J.W. Hofstraat. - 1992. Pattern classification with artificial neural networks: classification of algae, based upon flow cytometer data. Analytica Chimica Acta, 258: 11-25.

SooHoo, B.J., D.A. Kiefer, D.J. Collins and I.S. McDermid. - 1986. In vivo fluorescence excitation and absorption spectra of marine phytoplankton: I. Taxonomic characteristics and responses to photoadaptation. J. Plankton Res. 8(1): 197-214.

Sosik, H.M., S.W. Chisholm and R.J. Olson. - 1989. Chlorophyll fluorescence from single cells: Interpretation of flow cytometric signals. Limnol. Oceanogr. (Special Ocean Optics Issue) 34: 1749-1761.

Spinrad, R.W. - 1984. Flow cytometric analysis of the optical characteristics of marine particles. SPIE-Ocean Optics VII 489 335-342.

Spinrad, R.W. and J.F. Brown. - 1986. Relative real refractive index of marine microorganisms: a technique for flow cytometric estimation. Applied Optics 25(12): 1930-1934.
Steen, H.B., E. Boye, K. Skarstad, B. Bloom, T. Godal and S. Mustafa. - 1982. Applications of flow cytometry on bacteria: cell cycle kinetics, drug effects and quantitation of antibody binding. Cytometry 2: 249-257.

Tarran, G.A. and P.H. Burkill. - 1993. Flow cytometry at sea. In: D. A. Lloyd (Ed.), Flow Cytometry in Microbiology. SpringerVerlag, London. pp. 143- 158.

Tarran, G.A., P.H. Burkill and E.S. Edwards. - 1999. Phytoplankton community structure in the Arabian Sea during and after the SW Monsoon in - 1994. Deep-Sea Res. Part 2, Topical Stud. Oceanogr. 46(3-4): 655-676.

Timmermans, K.R., M.A. Van Leeuwe, J.T.M. De Jong, R.M.L. McKay, R.F. Nolting, H.J. Witte, J. Van Ooyen, M.J.W.Swagerman, H. Kloosterhuis and H.J.W. De Baar. - 1998. Iron stress in the Pacific region of the Southern Ocean: evidence from enrichment bioassays. Mar. Ecol. Progr. Ser., 166: 27-41.

Tintore, J., P. Velez, D. Gomis, S. Monserrat, J. Allen, T. Guymer, H. Roe, D. Smeed, P. Cipollini, J. Font, J.M. Beckers, M. Rixen, G. Corsini and M. Diani - 1998. Observations and modelling of eddy scale geostrophic and ageostrophic circulation: the OMEGA project. In: K.G. Barthel, H. Barth, M. Bohle-Carbonell, C. Fragakis, E. Lipiatou, P.Martin, G. Ollier and M. Weydert (eds.), European marine science and technology: Project synopses Vol. 1: 5-22, Commission of the European Community, Luxembourg.

Trask, B.J., G.J. van den Engh and J.H.B.W. Elgershuizen. - 1982. Analysis of phytoplankton by flow cytometry. Cytometry 2: 258-264.

Troussellier, M., M. Bouvy, C. Courties and C. Dupuy. - 1997. Variation of carbon content among bacterial species under starvation condition. Aquat. Microb. Ecol. 13: 113-119.

Troussellier, M., C. Courties and S. Zettelmaier. - 1995. Flow cytometric analysis of coastal lagoon bacterioplankton and picophytoplankton: Fixation and storage effects. Estuar. Coast. shelf Sci. 40: 621-633.

Turner, J.T., J. A. Lincoln and A. D. Cembella. - 1998. Effects of toxic and non-toxic dinoflagellates on copepod grazing, egg production and egg hatching success. In: B. Reguera, J. Blanco, M.L. Fernandez and T. Wyatt (eds.), Proceedings of VIII International Conference on Harmful Algae 1997, Vigo, Spain.

Van Bleijswijk, J.D.L., E.S. Kempers, M.J.W. Veldhuis and P. Westbroek. - 1994. Cell and growth characteristics of types A and B of Emiliania huxleyi (Prymnesiophyceae) as determined by flow cytometry and chemical analysis. J. Phycol. 30(2): 230-241

Van Bleijswijk, J.D.L. and M.J.W. Veldhuis. - 1995. In situ gross growth rates of Emiliania huxleyi in enclosures with different phosphate loading revealed by diel changes in DNA content. Mar. Ecol. Prog. Ser. 121: 271-277.

Van Leeuwe, M.A., K.R. Timmermans, H.J. Witte, G.W. Kraay, M.J.W. Veldhuis and H.J.W. De Baar. - 1998. Effects of iron stress on chromatic adaptation by natural phytoplankton communities in the Southern Ocean. Mar. Ecol. Progr. Ser. 166: 43-52.

Vaquer, A., M. Troussellier, C. Courties and B. Bibent. - 1996. Standing stock and dynamics of picophytoplankton in the Thau lagoon (northwest Mediterranean coast). Limnol. Oceanogr. 41: 1821-1828.

Vaulot, D., R.J. Olson, S. Merkel and S.W. Chisholm. - 1987. Cell cycle response to nutrient starvation in two phytoplankton species, Thalassiosira weissflogii and Hymenomonas carterae. Mar. Biol. 95: 625-630.

Vaulot, D., C. Courties and F. Partensky. - 1989. A simple method to preserve oceanic phytoplankton for flow cytometric analyses. Cytometry 10(5): 629-636.

Vaulot, D., R.J. Olson and S.W. Chisholm. - 1986. Light and dark control of the cell cycle in two marine phytoplankton species. Exp. Cell Res., 167: 38-52.

Vaulot, D., F. Partensky, J. Neveux, F.F.C. Mantoura and C.A. Llewellyn. - 1990. Winter presence of prochlorophytes in surface waters of the northwestern Mediterranean Sea. Limnol. Oceanogr. 35(5): 1156-1164.

Vaulot, D., D. Marie, R.J. Olson and S.W. Chisholm. - 1995. Growth of Prochlorococcus, a Photosynthetic Prokaryote, in the Equatorial Pacific Ocean. Science 268: 1480-1482.

Vaulot, D. and D. Marie. - 1999. Diel variability of photosynthetic picoplankton in the equatorial Pacific. J. Geophy. Res. Ocean. 104: 3297-3310.

Vazquez-Dominguez, E., F. Peters, J.M. Gasol and D. Vaqué - 
1999. Measuring the grazing losses of picoplankton: methodological improvements in the use of fluorescently labeled tracers combined with flow cytometry. Aquat. Microb. Ecol. 20: 119-128.

Veldhuis, M.J.W. and G.W. Kraay. - 1990. Vertical distribution and pigment composition of a picoplanktonic prochlorophyte in the subtropical North Atlantic: a combined study of HPLCanalysis and flow cytometry. Mar. Ecol. Prog. Series 68(1-2): 121-127.

Veldhuis, M.J.W. and G.W. Kraay. - 1993. Cell abundance and fluorescence of picophytoplankton in relation to growth irradiance and nitrogen availability in the Red Sea. Neth. J. Sea Res. 21: 135-45.

Veldhuis, M.J.W., T.L. Cucci and M.E. Sieracki. - 1997a. Cellular DNA content of marine phytoplankton using two new fluorochromes: taxonomic and ecological implications. J. Phycol. 33: $527-41$

Veldhuis, M.J.W., G.W. Kraaij, J.D.L. van Bleijswijk and M.A. Baars. - 1997b. Seasonal and spatial variability in phytoplankton biomass, productivity and growth in the north-western Indian Ocean (the SW- and NE-monsoon,1992-1993). Deep-Sea Res. 44: 425-449.

Vesey, G.P., J. Narai, N. Ashbolt, K. Williams and D.A. Veal. 1994. Detection of specific microorganisms in environmental samples using flow cytometry. In: Z. Darzynkiewicz, P. Robinson and H.A. Crissman (eds.), Methods in Cell Biology, Vol 42: 488 - 521. Flow Cytometry, Academic Press, Orlando, Florida.

Vesey, G.P. - 1996. Assessing Cryptosporidium parvum oocyst viability with fluorescent in situ hybridization using ribosomal RNA probes and flow cytometry). In: E. Bets et al., (eds.), Protozoan parasites in water, pp. 131-138. Royal Society for Chemistry, Cambridge, UK.

Visser, J.W.M., J. Haaijman and B.J. Trask. - 1978. Quantitative immunofluorescence in flow cytometry. In: W. Knapp, K. Holubar and G. Wick (eds.), Immunofluorescence and Related Staining Techniques. Elsevier/North-Holland Biomedical Press, Amsterdam.

Vrieling, E.G., W.W.C. Gieskes, T.W.M. Rademaker, G. Vriezekolk, L. Peperzak and M. Veenhuis. - 1995. Flow cytometric identification of the ichthyotoxic dinoflagellate Gyrodinium aureolum in the central North Sea. In: P. Lassus, G. Arzul, E. Erard, P. Gentien and C. Marcaillou, (eds.), Harmful Marine Algal Blooms, pp. 743-748. Lavoisier Sci. Publ. Paris, France.

Vrieling, E.G. and D.M. Anderson. - 1996. Immunofluorescence in phytoplankton research: applications and potential. J. Phycol. 32: $1-16$

Vrieling, E.G., G. Vriezekolk, W.W.C. Gieskes, M. Veenhuis and W. Harder. - 1996. Immuno-flow cytometric identification and enumeration of the ichthyotoxic dinoflagellate Gyrodinium aureolum Hulburt in artificially mixed algal populations. $J$. Plankton Res. (18): 1503-1512.

Vrieling, E.G., W.H. van de Poll, G. Vriezekolk and W.W.C. Gieskes. - 1997. Immuno-flow cytometric detection of the ichthyotoxic dinoflagellates Gyrodinium aureolum and Gymnodinium nagasakiense: independence of physiological state. $J$. Sea Res., 37(1/2): 91-100.

Waite, A.M., R.J. Olson, H.G. Dam and U. Passow. - 1995. Sugarcontaining compounds on the cell surfaces of marine diatoms measured using concanavalin A and flow cytometry. J. Phycol. 31: $925-933$.

Wallner, G., B. Fuchs, S. Spring, W. Beisker and R. Amann. 1997. Flow sorting of microorganisms for molecular analysis. Appl. Environ. Microbiol. 63(11): 4223-4231.

Ward, B.B. and M.J. Perry. - 1980. Immunofluorescent assay for the marine ammonium-oxidizing bacterium Nitrosococcus oceanus. Appl. Environ. Microbiol. 39(4): 913-918.

Weisse, T., and B. Kirchhoff. - 1997. Feeding of the heterotrophic freshwater dinoflagellate Peridiniopsis berolinense on cryptophytes: Analysis by flow cytometry and electronic particle counting. Aquat. Microb. Ecol. 12(2): 153-164.

Wiebenga, C., M.J.W. Veldhuis and H.J.W. de Baar. - 1997. Abundance and productivity of bacterioplankton in relation to seasonal upwelling in the northwest Indian Ocean. Deep-Sea Res. 44: 451-476.
Wietzorrek, J., M. Stadler and V. Kachel. - 1994. Flow Cytometric Imaging, implemented on the EurOPA flow cytometer - a novel tool for identification of marine organisms. In: Proceedings OCEANS '94 OSATES, Vol. 1: 688-693, IEEE, Piscataway, NJ-USA

Wilkins, M.F., C.W. Morris and L. Boddy. - 1994. A comparison of radial basis function and backpropagation neural networks for identification of marine phytoplankton from multivariate flow cytometry data. Cabios 10(3): 285-294.

Wilkins, M.F., L. Boddy, C.W. Morris and R.R. Jonker. - 1996. A comparison of some neural and non-neural methods for identification of phytoplankton from flow cytometry data. Cabios 12(1): 9-19.

Wood, A.M., P.K. Horan, K. Muirhead, D.A. Phinney, C.M. Yentsch and J.B. Waterbury. - 1985. Discrimination between types of pigments in marine Synechococcus spp. by scanning spectroscopy, epifluorescence microscopy and flow cytometry. Limnol. Oceanogr. 30(6): 1303-1315.

Xu, C., J. Auger and Govindjee. - 1990. Chlorophyll $a$ fluorescence measurements of isolated spinach thylakoids obtained by using single-laser-based flow cytometry. Cytometry 11(3): 349-358.

Yee, M.C. and J.C. Bartholomew. - 1988. Light regulation of the cell cycle in Euglena gracilis bacillaris. Cytometry 9(4): 387-93.

Yentsch, C.M. - 1981. Flow cytometric analysis of cellular saxitoxin in the dinoflagellate Gonyaulax-tamarensis-var-excavata. Toxicon 19(5): 611-622.

Yentsch, C.M., P.K. Horan, K. Muirhead, Q. Dortch, E. Haugen, L. Legendre, L.S. Murphy, M.J. Perry, D.A. Phinney, S.A. Pomponi, R.W. Spinrad, A.M. Wood, C.S. Yentsch and B.J. Zahuranec. - 1983a. Flow cytometry and cell sorting: a technique for analysis and sorting of aquatic particles. Limnol. Oceanogr. 28(6): 1275-1280.

Yentsch, C.M., F.C. Mague, P.K. Horan and K. Muirhead. - 1983b. Flow cytometric DNA determinations on individual cells of the dinoflagellate Gonyaulax-tamarensis-var-excavata. J. Exp. Mar. Biol. Ecol. 67(2): 175-184.

Yentsch, C.M. and S.A. Pomponi. - 1986. Automated individual cell analysis in aquatic research. Int. Rev. Cytol. 105: 183-243.

Yentsch, C.M., F.C. Mague and P.K. Horan - 1988. In: Immunochemical approaches to coastal, estuarine and oceanographic questions, pp. 184-193. Springer-Verlag, New York.

Yentsch, C.M. and P.K. Horan (eds.). - 1989. Cytometry in aquatic sciences. Special issue of Cytometry. Cytometry 10(5).

Yentsch, C.M. - 1990. Environmental Health: flow cytometric methods to assess our water world. In: Darzynkiewicz Z. and H.A. Crissman (eds.), Methods in cell biology. Vol. 33: Flow cytometry. Academic Press.

Yentsch, C.S., and C.M. Yentsch. - 1979. Fluorescence spectral signatures: the characterization of phytoplankton populations by the use of excitation and emission spectra. J. Mar. Res. 37: 471-483.

Zettler, E.R., R.J. Olson, B.J. Binder, S.W. Chisholm, S.E. Fitzwater and R. M. Gordon. - 1996. Iron-enrichment bottle experiments in the equatorial Pacific: Responses of individual phytoplankton cells. Deep Sea Res. II, 43(4-6): 1017-1029.

Zohary, T., S. Brenner, M.D. Krom, D.L. Angel, N. Kress, W.K.W Li, A. Neori and Y.Z. Yacobi. - 1998. Buildup of microbial biomass during deep winter mixing in a Mediterranean warmcore eddy. Mar. Ecol. Progr. Ser. 167: 47-57.

Zubkov, M.V., M.A. Sleigh, G.A. Tarran, P.H. Burkill and R.J.G. Leakey. - 1998. Picoplanktonic community structure on an Atlantic transect from $50^{\circ} \mathrm{N}$ to $50^{\circ} \mathrm{S}$. Deep Sea Res. Part I : Oceanogr. Res. Pap. 45(8): 1339-1355.

Zubkov, M.V., B.M. Fuchs, H. Eilers, P.H. Burkill and R. Amann. - 1999. Determination of Total Protein Content of Bacterial Cells by SYPRO Staining and Flow Cytometry. Appl. Environ. Microbiol. 65(7): 3251-3257.

Zubkov, M.V., M.A. Sleigh and P.H. Burkill. - 2000. Assaying picoplankton distribution by flow cytometry of underway samples collected along a meridional transect across the Atlantic Ocean. Aquat. Microb. Ecol. 21: 13-20. 